\title{
Organizational interventions improving access to community-based primary health care for vulnerable populations: a scoping review
}

Vladimir Khanassov ${ }^{1 *}$ (D), Pierre Pluye ${ }^{1}$, Sarah Descoteaux ${ }^{2}$, Jeannie L. Haggerty ${ }^{3}$, Grant Russell ${ }^{4}$, Jane Gunn ${ }^{5}$ and Jean-Frederic Levesque ${ }^{6}$

\begin{abstract}
Access to community-based primary health care (hereafter, 'primary care') is a priority in many countries. Health care systems have emphasized policies that help the community 'get the right service in the right place at the right time'. However, little is known about organizational interventions in primary care that are aimed to improve access for populations in situations of vulnerability (e.g., socioeconomically disadvantaged) and how successful they are. The purpose of this scoping review was to map the existing evidence on organizational interventions that improve access to primary care services for vulnerable populations. Scoping review followed an iterative process. Eligibility criteria: organizational interventions in Organisation for Economic Cooperation and Development (OECD) countries; aiming to improve access to primary care for vulnerable populations; all study designs; published from 2000 in English or French; reporting at least one outcome (avoidable hospitalization, emergency department admission, or unmet health care needs). Sources: Main bibliographic databases (Medline, Embase, CINAHL) and team members' personal files. Study selection: One researcher selected relevant abstracts and full text papers. Theory-driven synthesis: The researcher classified included studies using (i) the 'Patient Centered Access to Healthcare' conceptual framework (dimensions and outcomes of access to primary care), and (ii) the classification of interventions of the Cochrane Effective Practice and Organization of Care. Using pattern analysis, interventions were mapped in accordance with the presence/absence of 'dimension-outcome' patterns. Out of 8,694 records (title/abstract), 39 studies with varying designs were included. The analysis revealed the following pattern. Results of 10 studies on interventions classified as 'Formal integration of services' suggested that these interventions were associated with three dimensions of access (approachability, availability and affordability) and reduction of hospitalizations (four/four studies), emergency department admissions (six/six studies), and unmet healthcare needs (five/six studies). These 10 studies included seven non-randomized studies, one randomized controlled trial, one quantitative descriptive study, and one mixed methods study. Our results suggest the limited breadth of research in this area, and that it will be feasible to conduct a full systematic review of studies on the effectiveness of the formal integration of services to improve access to primary care services for vulnerable populations.
\end{abstract}

Keywords: Delivery of Health Care, Accessibility to Health Services, Vulnerable populations, Underserved populations, Organizational Interventions, Improve Access, Canada, Australia

\footnotetext{
* Correspondence: vladimir.khanassov@mail.mcgill.ca

'Department of Family Medicine, McGill University, 5858 Côte-des-neiges, 3rd

Floor, Suite 300, Montreal, QC H3S 1Z1, Canada

Full list of author information is available at the end of the article
} 


\section{Introduction}

Health systems are struggling to provide equitable access to community-based primary health care (hereafter, 'primary care') services $[1,2]$. The access to primary care services is worse for populations in situations of vulnerability (hereafter, 'vulnerable populations') such as poor, immigrant, and aboriginal citizens in Canada and Australia [3-6]. Emerging evidence from Canada and Australia shows that various reforms are aiming at improving access to care, but may not be well adapted to vulnerable populations $[7,8]$.

These access problems can pertain to the way care is offered as well as to the actual ability of people to seek, reach and engage with the care [9]. Organizational interventions might target both adjustments to the way care is delivered as well as targeting the development of people's capacity to obtain care [9]. While access-related problems for vulnerable populations have been documented, few reviews have looked at the evidence regarding how successful programs have been at addressing access issues for these populations [10].

Knowledge remains scant about the actual scope of interventions that go beyond the establishment of specific programs aimed at improving the usual way primary care is delivered for vulnerable populations. Therefore, the purpose of this scoping review was to describe the nature and breadth of published research studies in peer reviewed academic journals on organizational interventions improving access to primary care services for vulnerable populations, and reducing consequences of poor access in these populations.

\section{Review}

\section{Methods}

As part of the Australian-Canadian IMPACT program (Improving Models Promoting Access-to-Care Transformation), a scoping review was chosen to (i) map relevant studies regardless of the design, theoretical rationale, and discipline; and (ii) identify a candidate research focus for a subsequent systematic review [11, 12]. Scoping reviews are used to identify knowledge gaps, set research agendas, and identify implications for decision-making. Specifically, scoping reviews are aimed to explore the breadth of available evidence in a research domain (main available research studies), and map the concepts underpinning this domain, which can lead to plan and conduct a systematic literature review if enough evidence to answer a specific question [13, 14]. Scoping reviews typically include five iterative stages: definition of the research question, identification of the relevant studies, selection of the studies, charting of the data, collating, summarizing and reporting the results. We included studies with all types of design (comprehensive approach), followed an iterative process (e.g., adjustment of the search strategy), and involved experts (the last four coauthors) throughout.

\section{Definition of the research questions}

The specific research questions of the scoping review were as follows. What are the types of organizational interventions in primary care aiming at improving access for vulnerable populations? What are the documented impacts in terms of avoidable hospital admissions, emergency department presentations and unmet needs for care?

\section{Identification of the relevant studies}

This stage involved searching the following bibliographic databases: MEDLINE, Embase and CINAHL. The search strategy was designed by all co-authors, then validated and performed by a specialized librarian (example is presented in Appendix 1). The search was expanded using references in the selected studies and pertinent existing literature reviews (citation tracking). Given the scoping nature of our work, the grey literature was not searched.

Eligibility criteria were as follows: quantitative, or qualitative, or mixed methods study conducted in countries in the Organization for Economic Cooperation and Development (OECD); published in English or French between January 2000 and March 2014 (2000 was chosen as it corresponds to a shift, worldwide, towards community-based primary health care); about (i) vulnerable populations, i.e., socioeconomically disadvantaged (e.g., uninsured), racial and ethnic minorities (e.g., indigenous people), people with one or more chronic health condition (including mental illness), (ii) access-related interventions in primary care organizations, i.e., primary care setting, medical home, community health center (e.g., community mental health service), primary care services in other settings (e.g., school-based health care program), specialized care integrated in primary care settings (e.g., psychiatric team in a medical home), and (iii) evaluated impact on reduction of at least one of the following consequences of poor access: hospitalization, or emergency department admission, or unmet health care needs [9].

\section{Selection of the studies}

This stage consisted of an iterative process in which (contrary to a systematic review process) we searched the literature, refined our search strategy based on the new findings in the identified articles (e.g., if a new organizational intervention type has been identified we included it in searched words of database - MeSH to retrieve more studies), asked experts (JH, GR, GJ, J-FL) to share their personal files, and tracked citations in selected references and literature reviews. Using the eligibility criteria, relevant publications were selected 
by one researcher with extensive experience in systematic reviews (VK) [15-17] and in case of doubt discussed with another researcher (PP). The selection of records (title/abstract) was very sensitive, and the selection of full-text papers was specific. It was easy to exclude bibliographic records that were obviously not relevant. In case of doubt regarding a record, the corresponding full-text paper was automatically screened. Excluded full-text papers were obviously not relevant.

\section{Charting the data}

The following data were extracted from each included study: (i) author, year of publication, study country; (ii) study design (e.g., randomized controlled trial); (iii) study population (e.g., sample size); (iv) vulnerability context (e.g., elderly patients); (v) main characteristics of the intervention; (vi) other elements (e.g., cost); (vi) outcomes (hospitalization, emergency department admission and unmet health care needs).

\section{Collating, summarizing, and reporting the results}

We used a three-step qualitative synthesis: (Step 1) a classification of organizational interventions, (Step 2) a classification of access dimensions and outcomes of intervention, and (Step 3) a 'dimension/outcome' pattern analysis. Specifically, we conducted a theory-driven qualitative content analysis to classify interventions, dimensions and outcomes [18]. For each included study, we extracted key sentences eliciting the type of intervention, dimension and outcome (derived from previous classification and conceptual framework).

\section{Step 1. Classification of organizational interventions}

Interventions assessed in the included studies were categorized using the following financial and organizational types of intervention derived from the checklist of the Cochrane Effective Practice and Organization of Care Review Group (EPOC) [19]. The EPOC provides different categories (e.g., financial intervention) and subcategories of intervention. Based on the description of interventions in the included studies, the first author (VK) assigned them to the EPOC categories and subcategories. Typically, this classification was straightforward. In case of doubt, the study was discussed with the second author (PP) and the final classification was based on consensus.

1. Continuity of care via case management: Coordination of assessment, treatment and arrangement for referrals.

2. Formal integration of services: Bringing together services across sectors or teams (all services at one time).
3. Clinical multidisciplinary team: Creation of a team with professionals from multiple disciplines (or new team members).

4. Continuity of care via arrangement for follow-up.

5. Revision of professional role: Shifting of roles among healthcare professionals, or expansion of role to include new tasks.

6. Institution incentive: Financial reward to the organization or providers for doing specific action.

7. Capitation: Set amount per patient.

Step 2. Classification of access dimensions and outcomes Interventions assessed in the included studies were categorized using the 'Patient Centered Access to Healthcare' conceptual framework in terms of outcomes and dimensions [9]. First, the key outcomes were threefold: reduction of avoidable hospitalization, emergency department admission, and unmet health care needs (Fig. 1). These outcomes were chosen because they are commonly proposed in the literature and institutionalized in research funding and governmental agencies [20-23]. For example, numerous studies demonstrated that increasing access to primary care services is associated to an improvement of these three outcomes. As another example, these outcomes were chosen by the Canadian Institutes of Health Research as national priorities for primary care studies and research teams [24]. Second, the key dimensions of access were as follows.

1. Approachability: Existence of reachable services.

2. Availability: Getting services in time.

3. Affordability: Financial capacity necessary to use services.

4. Acceptability: Cultural and social acceptance of services.

5. Appropriateness: Fit between services needed and obtained.

\section{Step 3. 'Dimension/outcome' pattern analysis}

Patterns were suggested when groups of studies on similar interventions were associated with similar access dimensions and similar outcomes (positive versus no effect). Within groups, each study had the same weight regardless of their design. We looked for 'dimensions of access to primary care services and outcomes' patterns (dimensionoutcome patterns). We grouped studies that shared a given type of outcome (e.g., emergency department admission) and we searched for their shared conditions (presence/absence of each access dimension). Outcomes were categorized and coded as "positive" (reduction of avoidable hospitalization, emergency department admission, and unmet health care needs) or "no effect" (no reduction). For each group, a pattern is suggested when all studies (or almost all) had similar outcomes and access 


\section{Policies, institutions, organisations and processes}

\section{Health care services (health facilities, private practice, drug shop and others)}

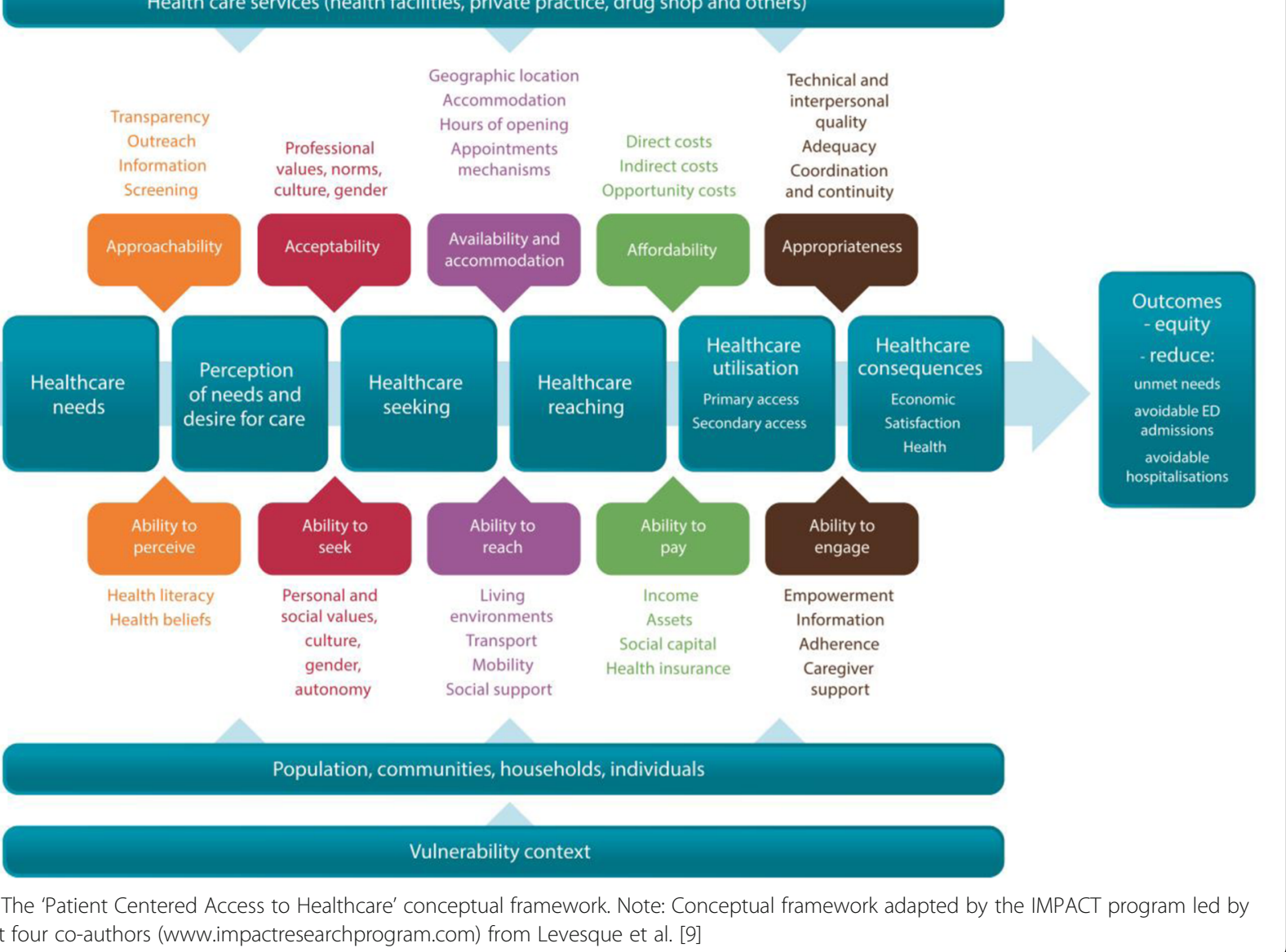

dimensions (vote counting). This pattern analysis was conducted without and with consideration of the vulnerable population type (e.g., elderly patients versus uninsured persons).

\section{Results}

\section{Search results}

The search results are outlined in a flow chart (Fig. 2). Out of 8,694 records, 6,943 were not eligible based on the title and/or the abstract, and 1,721 were excluded based on the full-text publications. An additional nine eligible studies were identified through citation tracking and personal files of researchers, leading to include 39 studies in total (Fig. 2).

\section{Description of included studies}

Twenty-six studies were conducted in the USA [25-51], six in Canada [52-57], three in the UK [58-60], two in New Zealand [34, 61], one in Australia [62] and one in Italy [63] (Table 1). Thirty-six were quantitative studies including 11 randomized controlled trials [35-43, 49, 51,
$55,62], 22$ non-randomized studies [25, 27-34, 44-48, $51,53,54,58-60,63,64]$, three quantitative descriptive studies [26, 52, 61], and three mixed methods studies (Table 1) [34, 50, 56]. Twenty-five studies (64.1\%) concerned patients with chronic conditions, and 14 examined (35.9\%) socioeconomically disadvantaged populations (Table 2).

Thirty-five studies (89.7\%) concerned organizational interventions, including revision of professional roles $[61,62]$, clinical multidisciplinary teams $[44,45,50,52$, $54]$, formal integration of services [26, 29, 31, 33, 34, 41, $46,53,56,64,65]$, and continuity of care via case management [27, 30, 32, 35-40, 43, 47, 49, 51, 55, 60, 63] or arrangements for follow-up [48, 57]. Four studies (10.3\%) concerned financial interventions, namely institution incentives $[28,58,66]$ and capitation [25].

\section{Description of the organizational interventions Continuity of care via case management}

This organizational intervention is designed to coordinate different medical and social services via a case manager 


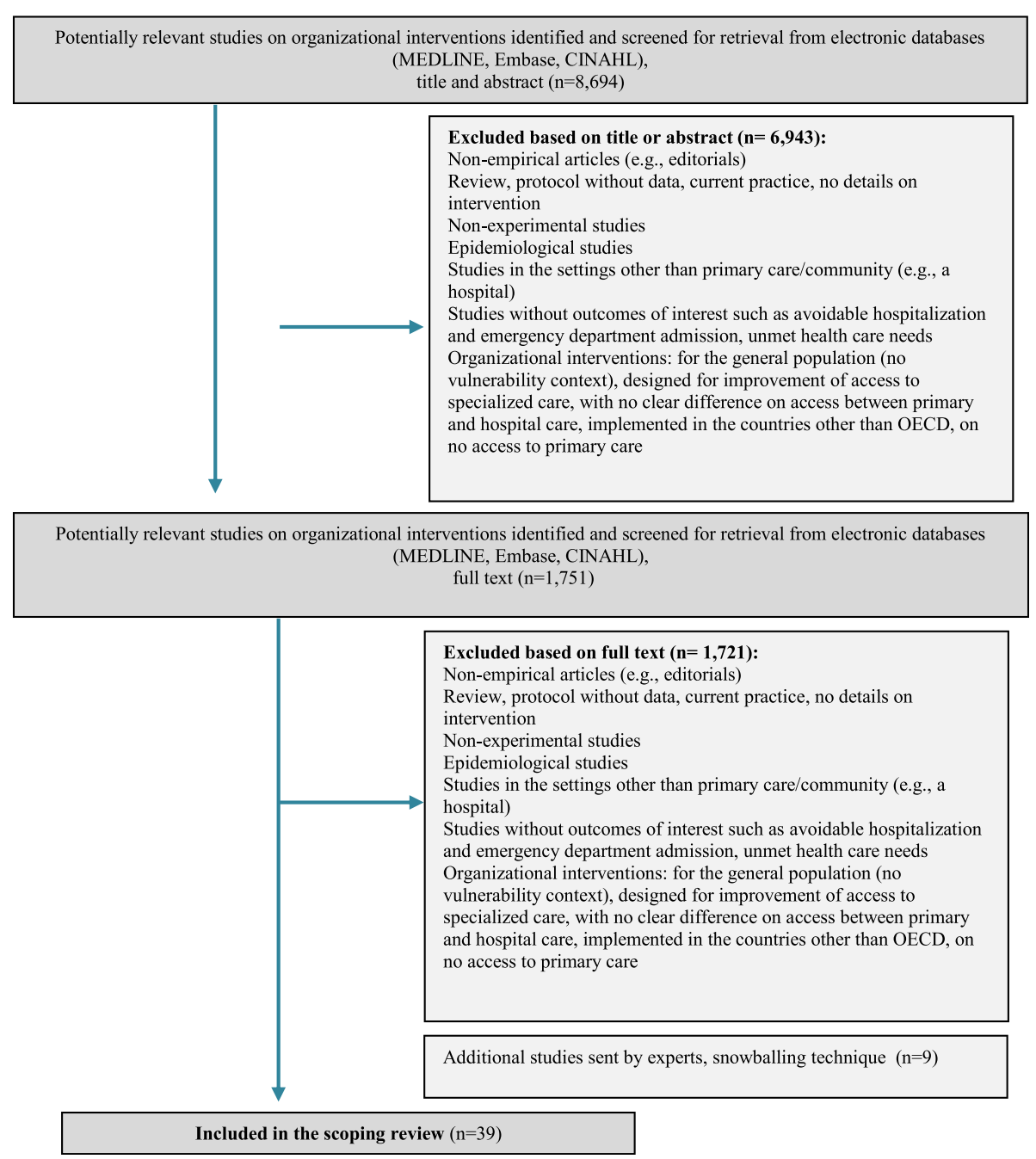

Fig. 2 Flow Chart

(i.e., a nurse) who closely works with PCP [27, 30, 32, $35-40,43,47,49,51,55,60,63]$. A case manager is responsible for assessment of care needs, development of care plan in collaboration with other health care professionals, regular follow-up and liaison of services. In the identified studies majority of participants were elderly patients with multiple chronic conditions and functional disabilities $[35,38,39,49,51,55,59,60$, 63]. Other categories of the patients were uninsured $[30,40,47]$ and formerly incarcerated people [37, 43], children with special health care needs [27, 32], and patients with psychiatric disorders [36].

\section{Formal integration of services}

This organizational intervention targets to bring all services (medical and social) at one point $[44,45,50,52$, 54]. Four types of intervention strategies have been used in the identified studies. The first strategy was to bring together primary care and secondary/tertiary services, i.e., integrate specialists into primary care settings such as mental health teams $[29,41,42,65]$, community service teams [26], and alcohol-substance abuse counselors [31]. The second strategy was for brokers or community health workers to identify proactively eligible patients (e.g., in the emergency room) and assign them to a primary care practitioner $[31,33,34,46]$. Third, a network was developed and integrated services using a 'single entry point' (integration of home care, rehabilitation and hospital services) with 24/7 telephone access [53, 64]. Fourth, informatics-based integration allowed virtual monitoring of complex health conditions from primary care to hospital-based services (telehomecare) [56]. The main categories of vulnerable populations targeted by this intervention were patients with low income or uninsured [26, 31, 33, 34, 46], patients with mental health problems $[29,41,65]$, and elderly patients with multiple chronic conditions $[53,56]$. 
Table 1 Description of included studies

\begin{tabular}{|c|c|c|c|c|c|}
\hline $\begin{array}{l}\text { Author/year/ } \\
\text { country }\end{array}$ & Study design & $\begin{array}{l}\text { Population (participants } \\
\text { and setting) }\end{array}$ & Vulnerability context & Main characteristics of the intervention & Other elements \\
\hline \multicolumn{6}{|c|}{ Revision of professional roles } \\
\hline $\begin{array}{l}\text { Gray, 2013/ } \\
\text { New Zealand } \\
\text { [61] }\end{array}$ & Quantitative descriptive & $\begin{array}{l}\text { Sample size: } 400 \\
\text { Age: not reported. } \\
\text { Patients: Children with } \\
\text { rheumatic fever caused } \\
\text { by the Group A } \\
\text { Streptococcal infections. } \\
\text { Setting: primary school }\end{array}$ & $\begin{array}{l}\text { Children of primary school (1-8 } \\
\text { years old), ethnic composition } \\
\text { (Pacific and Maori). }\end{array}$ & $\begin{array}{l}\text { Nurse-led school-based clinics: } \\
\text { - social worker (ethnicity of whanau) was trained in } \\
\text { recognition of skin infection and swabbing of sore } \\
\text { throats; } \\
\text { - identification of students with symptoms of a sore } \\
\text { throat by the social worker under the supervision of } \\
\text { the public health nurse; } \\
\text { - medical treatment by a public health nurse (antibiotics } \\
\text { and ointment) guided by the evidence-based } \\
\text { guidelines; } \\
\text { - referral of students with skin infection by the social } \\
\text { worker to the public health nurse for the full } \\
\text { assessment; } \\
\text { - education of the parents on the importance and } \\
\text { adherence to the medical treatment; } \\
\text { - regular phone follow-up by the public health nurse; } \\
\text { - assessment and treatment of household members at } \\
\text { home. }\end{array}$ & $\begin{array}{l}\text { Annual cost: } \$ 510 \text { per student } \\
\text { (\$10 for consumables, } \$ 80 \text { for } \\
\text { diagnostic services, } \$ 420 \text { for } \\
\text { staffing costs). }\end{array}$ \\
\hline \multicolumn{6}{|c|}{ Clinical multidisciplinary teams } \\
\hline $\begin{array}{l}\text { McDermott, } \\
\text { 2001; 2004/ } \\
\text { Australia [62] }\end{array}$ & $\mathrm{RCT}$ & $\begin{array}{l}\text { Sample size: } 21 \text { primary } \\
\text { healthcare centers ( } 921 \\
\text { people) } \\
\text { Age: } 53.3 \pm 13.6 \text { vs } 52.4 \\
\pm 14 \\
\text { Patients: Patients with } \\
\text { diabetes (type } 2 \text { ) } \\
\text { Setting: primary care }\end{array}$ & $\begin{array}{l}\text { People with diabetes from } \\
\text { remote indigenous } \\
\text { communities }\end{array}$ & $\begin{array}{l}\text { - implementation by the local indigenous health } \\
\text { workers supported by a specialist outreach service in } \\
\text { the } 21 \text { primary healthcare centers of the Torres Strait } \\
\text { District: } \\
\text { (i) registers of patients with diabetes; } \\
\text { (ii) recall and reminder systems; } \\
\text { (iii) basic diabetes care plans; } \\
\text { - training of the local indigenous health workers in } \\
\text { clinical diabetes care; } \\
\text { - two-monthly newsletters. }\end{array}$ & \\
\hline $\begin{array}{l}\text { Doey, 2008/ } \\
\text { Canada [54] }\end{array}$ & NRS & $\begin{array}{l}\text { Sample size: } 380 \\
\text { (survey), } 805 \text { (charts) } \\
\text { Age: } 40.7 \pm 15.2 \\
\text { Sex (female): } 51 \% \\
\text { Patients: Patients with } \\
\text { mental diseases } \\
\text { Setting: community } \\
\text { mental health clinic }\end{array}$ & $\begin{array}{l}\text { Patients with mental diseases } \\
\text { such as depression, bipolar } \\
\text { disorder, schizophrenia, } \\
\text { psychosis, personality disorder }\end{array}$ & $\begin{array}{l}\text { Collaborative care: } \\
\text { - nurse practitioner was hired to provide primary care } \\
\text { services in collaboration with the existing team of } \\
\text { mental healthcare professionals (including nurses, } \\
\text { social workers, a psychiatrist, a psychologist) in a } \\
\text { community mental health clinic; } \\
\text { - nurse practitioner's responsibilities were assessment } \\
\text { and treatment of non-psychiatric acute and chronic } \\
\text { diseases, physical examination, counseling on diet, ex- } \\
\text { ercise, substance abuse, } \\
\text { - the hospitalist (PCP) from the hospital treated patients } \\
\text { outside the nurse's scope of practice (5 afternoons per } \\
\text { week); } \\
\text { - availability of the physician by phone and e-mail be- } \\
\text { tween visits. }\end{array}$ & $\begin{array}{l}\text { External funding was allocated to } \\
\text { hire nurse practitioners. }\end{array}$ \\
\hline
\end{tabular}

mealthcare centers $(921$

Patients: Patients with

diabetes (type 2)

Setting: primary care

(female): $51 \%$

mental diseases

etting: community 
Table 1 Description of included studies (Continued)

\begin{tabular}{|c|c|c|c|c|c|}
\hline $\begin{array}{l}\text { Crustolo, 2005/ } \\
\text { Canada [52] }\end{array}$ & Quantitative descriptive & $\begin{array}{l}\text { Sample size: } 4,280 \\
\text { referrals annually } \\
\text { Age: } 45 \% \text { were } 45-64 \\
\text { years old } \\
\text { Patients: Patients with } \\
\text { nutrition-related health } \\
\text { conditions. } \\
\text { Setting: primary care }\end{array}$ & $\begin{array}{l}\text { Patients with dyslipidemia, } \\
\text { type } 2 \text { diabetes, obesity. }\end{array}$ & $\begin{array}{l}\text { Shared care model of collaboration of PCP and dietitian: } \\
\text { - primary care practice received } 10 \mathrm{~h} \text { of nutrition } \\
\text { services per month (half a day each week); } \\
\text { - registered dietitian provided assessment of patients } \\
\text { and consultation of PCP on nutrition-related problems; } \\
\text { - patients were referred by the PCP (within } 2 \text { weeks after } \\
\text { referral). }\end{array}$ & $\begin{array}{l}\text { The Provincial Ministry of Health } \\
\text { funded the intervention program } \\
\text { in primary care practices. }\end{array}$ \\
\hline $\begin{array}{l}\text { McCuloch, } \\
\text { 2000/USA [45] }\end{array}$ & NRS & $\begin{array}{l}\text { Sample size: } 15,000 \\
\text { (approximately) } \\
\text { Age: not reported. } \\
\text { Patients: Patients with } \\
\text { diabetes } \\
\text { Setting: Managed care } \\
\text { (200 PCPs practicing in } \\
25 \text { clinics) }\end{array}$ & Patients with diabetes & $\begin{array}{l}\text { Group Health Cooperative program: } \\
\text { - development of electronic registry of patients with } \\
\text { diabetes updated daily; } \\
\text { - joint examination of patients by PCP, diabetologist, } \\
\text { and diabetes nurse specialist (at least one visit); } \\
\text { - application of evidence-based diabetes guidelines (ret- } \\
\text { inal screening, microalbuminuria, and glycemic } \\
\text { management; } \\
\text { - use of patient-friendly notebook for self-management. }\end{array}$ & $\begin{array}{l}\text { Decrease in diabetic per member } \\
\text { per month costs of } \$ 62 \text {. }\end{array}$ \\
\hline $\begin{array}{l}\text { Michelen, 2006/ } \\
\text { USA [44] }\end{array}$ & NRS & $\begin{array}{l}\text { Sample size: } 1,250 \\
\text { (539 vs } 711) \\
\text { Age (1-5 years): } 27.1 \% \\
\text { Ethnicity: } 92.1 \% \text { of } \\
\text { Hispanic } \\
\text { Patients: Uninsured } \\
\text { immigrants } \\
\text { Setting: primary care, } \\
\text { community health } \\
\text { services }\end{array}$ & $\begin{array}{l}\text { Uninsured immigrants with } \\
\text { frequent use of the ED for } \\
\text { preventable crisis. }\end{array}$ & $\begin{array}{l}\text { The Northern Manhattan Community Voices partners } \\
\text { program: } \\
\text { - recruitment of a native Spanish speaker Health Priority } \\
\text { Specialist experienced and knowledgeable of the } \\
\text { target community and medical services; } \\
\text { - recruitment of linguistically similar to the target } \\
\text { population Community Health Workers; } \\
\text { - Community Health Workers centered on direct patient } \\
\text { and community outreach and assessment; } \\
\text { - Community Health Workers was physically located } \\
\text { within their community. } \\
\text { - Health Priority Specialist were located in community } \\
\text { medical centers; } \\
\text { - identification of frequent users of ED and assistance to } \\
\text { find appropriate primary care services. }\end{array}$ & \\
\hline $\begin{array}{l}\text { Driscoll, 2013/ } \\
\text { USA [50] }\end{array}$ & $\begin{array}{l}\text { Mixed methods study } \\
\text { (sequential explanatory } \\
\text { design) }\end{array}$ & $\begin{array}{l}\text { Sample size: } 3,213 \\
\text { (390 vs 2,823) } \\
\text { Age: not reported } \\
\text { Participants: Alaska } \\
\text { Native/Indian population, } \\
\text { adults with asthma } \\
\text { Setting: primary care }\end{array}$ & $\begin{array}{l}\text { The Alaska Native and } \\
\text { American Indian population, } \\
\text { patients with asthma }\end{array}$ & $\begin{array}{l}\text { Patient-centered medical home: } \\
\text { - matching of the patient to the team of medical home } \\
\text { (self-selection or assignment); } \\
\text { - open scheduling of the appointment; } \\
\text { - expanded office hours; } \\
\text { - increased ability of electronic communication between } \\
\text { patients and healthcare professionals; } \\
\text { - delivery of care by the multidisciplinary team: PCP, } \\
\text { physician assistant, nurse, certified medical assistant, } \\
\text { behavioral health consultants, nutritionists; } \\
\text { - delegation of more authority by the physicians to non- } \\
\text { physician members (behavioral health consultants). }\end{array}$ & \\
\hline
\end{tabular}


Table 1 Description of included studies (Continued)

\begin{tabular}{|c|c|c|c|c|}
\hline \multicolumn{5}{|c|}{ Formal integration of services } \\
\hline $\begin{array}{l}\text { Day, 2006/UK } \\
\text { [65] }\end{array}$ & NRS & $\begin{array}{l}\text { Sample size: } 289 \\
\text { (126 vs 163) } \\
\text { Age: } 0-18 \\
\text { Diseases: Children with } \\
\text { mental health conditions. } \\
\text { Setting: primary care }\end{array}$ & $\begin{array}{l}\text { Children } 0 \text { to } 18 \text { years old with } \\
\text { mental health conditions }\end{array}$ & $\begin{array}{l}\text { Adolescent mental health outreach clinics: } \\
\text { - staffed with three clinical child psychologists, one child } \\
\text { and family therapist; } \\
\text { - assessment and treatment of broad range of mental } \\
\text { health problems; } \\
\text { - referral of patients with more complex conditions to } \\
\text { the specialist clinics; } \\
\text { - referral to the outreach clinics were accepted from any } \\
\text { sources (majority from PCPs). }\end{array}$ \\
\hline $\begin{array}{l}\text { Garg, 2012/USA } \\
{[26]}\end{array}$ & Quantitative descriptive & $\begin{array}{l}\text { Sample size: } 1059 \\
\text { families } \\
\text { Age: not reported. } \\
\text { Participants: Low- } \\
\text { income people } \\
\text { Setting: Medical home }\end{array}$ & Low-income people & $\begin{array}{l}\text { Health lead model: } \\
\text { - completing a brief screening survey for social issues } \\
\text { (e.g., food, housing) by parents at well-child care visit; } \\
\text { - referral to the intervention team located in the } \\
\text { pediatric clinic; } \\
\text { - volunteer undergraduate students assist with } \\
\text { connecting families to community-based resources } \\
\text { through in-person meetings and telephone follow-up; } \\
\text { - follow-up by the students; } \\
\text { - update of referring physicians (e.g., pediatric primary } \\
\text { care provider, nurse practitioner) on health outcomes. }\end{array}$ \\
\hline $\begin{array}{l}\text { Lamothe, 2006/ } \\
\text { Canada [56] }\end{array}$ & $\begin{array}{l}\text { Mixed methods study } \\
\text { (convergent parallel } \\
\text { design) }\end{array}$ & $\begin{array}{l}\text { Sample size: } 82 \\
\text { Age: } 75 \text { and older } \\
\text { Participants: Elderly } \\
\text { patients with severe } \\
\text { chronic conditions } \\
\text { Setting: primary care } \\
\text { and community (home } \\
\text { of patients) }\end{array}$ & $\begin{array}{l}\text { Elderly patients with severe } \\
\text { chronic conditions: cardiac } \\
\text { insufficiency, chronic } \\
\text { obstructive pulmonary } \\
\text { diseases, hypertension, } \\
\text { unstable diabetes }\end{array}$ & $\begin{array}{l}\text { Telehomecare to create a network of services between } \\
\text { hospital and primary care providers. } \\
\text { - equipment installed at patients' home (a scale, } \\
\text { thermometer, sphyngmomanometer, oxymeter, and } \\
\text { pulse; if needed glucometer, spirometer, } \\
\text { electrocardiograph, and a system for the measure of } \\
\text { blood clotting); } \\
\text { - sending of measures on a daily basis to the primary } \\
\text { care setting; } \\
\text { - nurse of primary care responsible for monitoring and } \\
\text { responding to alerts from patients; } \\
\text { - telephone and home follow-up by the nurse if } \\
\text { needed. }\end{array}$ \\
\hline $\begin{array}{l}\text { Tourigny, 2004; } \\
\text { Hebert, 2010/ } \\
\text { Canada [53, 64] }\end{array}$ & NRS & $\begin{array}{l}\text { Sample size: } 920 \\
\text { (501 vs 419) } \\
\text { Age: } 83 \\
\text { Sex (female): } 67 \% \\
\text { Participants: Elderly } \\
\text { people } \\
\text { Setting: primary care }\end{array}$ & $\begin{array}{l}\text { Elderly people at risk of } \\
\text { functional decline }\end{array}$ & $\begin{array}{l}\text { Program of Research to Integrate Services for the } \\
\text { Maintenance of Autonomy (PRISMA): } \\
\text { - coordination between decision makers and managers } \\
\text { at the regional and local levels; } \\
\text { - the "single entry point" (mechanism of accessing the } \\
\text { services such as home care, rehabilitation services, } \\
\text { hospital services, voluntary agencies, social economy } \\
\text { agencies); it can be access by the telephone or written } \\
\text { referral; }\end{array}$ \\
\hline
\end{tabular}


Levkoff, 2004; RCT

$[41,42]$

Brown, 2005/

USA [29]

Mackinney,

2013/USA [33]
Sample size: 2,022

(999 vs 1,023 )

Age: 65 and older

Patients: Patient with

mental health

conditions

Setting: primary care

Sample size: 17

Age: 41

Sex (female): $65 \%$

Patients: Patients with

mental health problems

Setting: primary care

Sample size: 278

(278 vs 278)

Age: not reported.

Patients: Uninsured

population

Setting: primary care
24/7 access to the general population through Health

Info Line;

- use of "the single assessment instrument" for

evaluating needs coupled with case-mix management

system;

development of the individualized service plan in

collaboration of PCPs with multidisciplinary team;

- computerized clinical chart to facilitate communication

between organizations and healthcare professionals.

Patients with mental health Integrated care model:

conditions such as depression, - co-location of mental health and substance abuse

anxiety, at risk drinking services in primary care facility;

mental health and substance abuse services include assessment, care planning, counseling, psychotherapy, pharmacological treatment);

- PCPs required to be closely involved in the patient's care.

Patients with psychiatric health Primary intensive care:

conditions (e.g., depression, Integration of mental health services in primary care

panic disorder) and with high facility:

level of medical admission, ED - location of an internist, psychiatrist-internist, nurse

visits, frequent outpatient

practitioner, and social worker in primary care;

calls.

usual time;

- multidisciplinary assessment and follow-up:

- frequent visits to the clinic (weekly initially):

$-24 / 7$ availability of a team member on call via pager.

- development of care plan in collaboration with PCP.

Uninsured patients (18 years Project Access Program (Milwaukee):

old and older) with income - identification of uninsured individuals via an

less than $200 \%$ of the Federal administrative system by the county social worker;

Poverty Level - identification of healthcare providers willing to provide

free services via online, radio, newspaper public

advertising;

connections of the person in need of primary care

services with a provider:

- delivery of full-spectrum basic laboratory and non-

invasive radiology services;

- no pharmacy component

Uninsured patients with

Community-based coordinated care program:

Post-intervention total hospital cost was lower $(p=\mathrm{NS})$.

income less than $200 \%$ of the - identification of uninsured patients in ED, outpatient or year fell by $50 \%(p<0.01)$

Over 3 years, inpatient costs per

Federal Poverty Level_ inpatient settings;

- assistance with financial eligibility forms;

- assignment of the primary care provider willing to

provide primary care services to this category of

patients;

- remuneration of primary care providers: monthly

management fee and fee-for-services 
Table 1 Description of included studies (Continued)

\begin{tabular}{|c|c|}
\hline $\begin{array}{l}\text { Kaufman, 2000/ NR } \\
\text { USA [31] }\end{array}$ & $\begin{array}{l}\text { Sample size: } 23,143 \\
\text { (10,029 vs } 13,114) \\
\text { Age (19-49): } 69.5 \% \\
\text { Sex (female): } 68.6 \% \\
\text { Patients: Uninsured } \\
\text { patients } \\
\text { Setting: primary care }\end{array}$ \\
\hline
\end{tabular}

Uninsured patients below

$235 \%$ of the Federal Poverty

Level not eligible for Medicaid

Managed care: hospitals;

- assignment of eligible patients to preferred PCPs;

- each patient received a care plan identification card listing his/her PCP;

- monthly premium ranged from $\$ 0$ to $\$ 10$ for primary care visits depending upon income level;

- the benefit package also includes reduced out-of-

pocket cost of medications, access to 24/7 telephone triage system; behavioral health service is not covered. - increase of staff ( 12 new PCPs and 5 new family nurse practitioners);

- extension of clinic hours;

relocation of case managers and social workers from inpatient to primary care clinics,

- relocation of alcohol and substance abuse counselors to primary care clinics.

Poverty Level

Setting: primary care

Continuity of care via case management

Beland, 2006/

$\mathrm{RCT}$

Canada [55]
Sample size: 1230

(606 vs 624)

Age: 82 vs 82

Sex (female):
Elderly patients with chronic

diseases and functional

disabilities
Medical services initiative program (a safety-net-based system):

- eligible patients are identified at the time they seek for health services;

- patient is assigned to a medical home within which they choose or are assigned to the primary care provider:

patients were eligible for at least one visit to medical home within 12 months;

- patients with diabetes, congestive heart failure,

hypertension, asthma are required to see a doctor at least twice within 12 months;

- multidisciplinary team consists of PCP, nurses, nurse practitioners, case managers/social workers;

- information system connected emergency rooms and community clinics to get a history of disease by the physicians of ED;

- this electronic system allowed to refer patients to their PCPs in case of nonemergent conditions;

- emergency phone line staffed with registered nurses is available 24/7;

- reimbursement: \$15 to ED physicians for entering clinical information in the electronic system and \$100 to community clinics for acceptance of referral from emergency.

System of Integrated Care for Older Persons (SIPA): Two public community organizations responsible for home care (Centre Local de Services Communautaires) conducted:
The primary care clinics received: per month as compensation: Medicaid professional primary care services capitation rate; reduced fee-for-service rate for specialists.

Savings of $\$ 148$ per member per year on the cost of outpatient and inpatient care.

PCPs are reimbursed on a fee-forservice rate based on $70 \%$ of the

Medicare fee schedule. Private

providers received incentives to

join the network and pay-for-

performance payments for

primary and preventive services. - capitation of $\$ 4$ per plan member

- compensation of PCPs for their time communicating with the research team ( $\$ 400$ per patient annually); 
Table 1 Description of included studies (Continued)

\begin{tabular}{|c|c|c|c|c|}
\hline & & $\begin{array}{l}71 \% \text { vs } 72 \% \\
\text { Participants: Disabled } \\
\text { elderly patients } \\
\text { Setting: primary care }\end{array}$ & & $\begin{array}{l}\text { - comprehensive geriatric assessment; } \\
\text { - assessment of patients' needs; } \\
\text { - development of care plan in collaboration with PCP; } \\
\text { - mobilization and delivery of community services; } \\
\text { - availability of 24-h on-call services; } \\
\text { - patients were followed between hospital and } \\
\text { community. }\end{array}$ \\
\hline $\begin{array}{l}\text { Glendenning- } \\
\text { Napoli, 2012/ } \\
\text { USA [30] }\end{array}$ & NRS & $\begin{array}{l}\text { Sample size: } 83 \\
\text { Age (50-65): } 76 \% \\
\text { Sex (female): } 60.2 \% \\
\text { Patients: Uninsured } \\
\text { patients } \\
\text { Setting: primary care }\end{array}$ & $\begin{array}{l}\text { Uninsured patients with one } \\
\text { or more chronic diseases } \\
\text { (diabetes mellitus, } \\
\text { hypertension, congestive heart } \\
\text { failure, coronary artery disease) } \\
\text { with frequent admissions to } \\
\text { the ED and hospital }\end{array}$ & $\begin{array}{l}\text { Intensive case management program: } \\
\text { - identification of patients with frequent use of ED and } \\
\text { frequent hospitalizations; } \\
\text { - in-home assessment of patient's needs by a registered } \\
\text { nurse (identification of barriers to accessing health } \\
\text { care, health literacy level); } \\
\text { - accompany of patients to PCP to engage patients in } \\
\text { their care; } \\
\text { - development of preventive care plan; } \\
\text { - in collaboration with social worker identification of } \\
\text { patient's need for social programs; } \\
\text { - telephone follow-up and home visits to reinforce the } \\
\text { intervention; } \\
\text { - in-home education sessions on available pharmacy } \\
\text { assistance programs. }\end{array}$ \\
\hline $\begin{array}{l}\text { Leff, 2009; } \\
\text { Boult, 2011/USA } \\
{[35,59]}\end{array}$ & $\mathrm{RCT}$ & $\begin{array}{l}\text { Sample size: } 835 \\
\text { (433 vs 402) } \\
\text { Age: not reported. } \\
\text { Patients: Older patients } \\
\text { Setting: Managed care }\end{array}$ & $\begin{array}{l}\text { Older patients ( } 65 \text { years and } \\
\text { older) at high risk of using } \\
\text { health services }\end{array}$ & $\begin{array}{l}\text { Practice-based team intervention: } \\
\text { - in-home comprehensive assessment of needs by a } \\
\text { nurse (caseload } 50 \text { to } 60 \text { patients); } \\
\text { - development of the care plan; } \\
\text { - facilitation of the access to community resources; } \\
\text { - monthly follow-up; } \\
\text { - coordination of all patient care providers; } \\
\text { - facilitation of transition between care practices; } \\
\text { - education and support of caregivers. }\end{array}$ \\
\hline $\begin{array}{l}\text { Shah, 2011/USA } \\
\text { [47] }\end{array}$ & NRS & $\begin{array}{l}\text { Sample size: } 258 \\
\text { ( } 98 \text { vs 160) } \\
\text { Age: } 46.4 \pm 9.6 \text { vs } 46 \pm \\
10.7 \\
\text { Sex (female): } 40.8 \% \text { vs } \\
53.1 \% \\
\text { Patients: Uninsured } \\
\text { population } \\
\text { Setting: Managed care }\end{array}$ & $\begin{array}{l}\text { Uninsured Medicaid } \\
\text { population, frequent users of } \\
\text { ED ( } 4 \text { or more ED admissions, } \\
3 \text { or more admissions, } 2 \text { or } \\
\text { more admissions and one ED } \\
\text { visit within } 1 \text { year) }\end{array}$ & $\begin{array}{l}\text { Managed Care program: } \\
\text { - identification of uninsured frequent users of } \\
\text { emergency room; } \\
\text { - assignment of a personal care manager who assists } \\
\text { with access to social and medical resources; } \\
\text { - personal care manager helps schedule an appointment } \\
\text { with a PCP; } \\
\text { - personal care manager helps bridge barriers between } \\
\text { patients and health care system; } \\
\text { - monthly meeting of case manager with patients (at } \\
\text { home, resource centers, at appointment); } \\
\text { - individually developed care plan; } \\
\text { - daily work of case manager with a patient in case of } \\
\text { hospital admission. }\end{array}$ \\
\hline
\end{tabular}

$44 \%$ higher community costs; $22 \%$ lower total institution costs;

- overall the intervention was neutral;

no difference in out-of-pocket costs.

reduction in cost for acute outpatient visits $(p<0.009)$ and inpatient hospitalizations $(p<$

0.002);

- increase in cost for primary care visits $(p<0.02)$.

Net savings (2/3 due to

reductions in hospital utilization).

Age: not reported.

Patients: Older patients

Setting: Managed care

Sex (female): $40.8 \%$ vs

$53.1 \%$

ents: Uninsured

population

Setting: Managed care 
Table 1 Description of included studies (Continued)

\begin{tabular}{|c|c|c|c|c|c|}
\hline $\begin{array}{l}\text { Wang, 2012/ } \\
\text { USA [43] }\end{array}$ & $\mathrm{RCT}$ & $\begin{array}{l}\text { Sample size: } 200 \\
\text { (98 vs 102) } \\
\text { Age: } 42.9 \pm 9.7 \text { vs } 43.6 \pm \\
8.3 \\
\text { Sex (female): } 8.2 \% \text { vs } \\
3.5 \% \\
\text { Patients: Individuals } \\
\text { released from prison } \\
\text { Setting: primary care }\end{array}$ & Formerly incarcerated people & $\begin{array}{l}\text { Primary care-based, complex care management: } \\
\text { - primary care services provided by a provider with } \\
\text { experience working with this population and a } \\
\text { community health worker with a personal history of } \\
\text { incarceration; } \\
\text { Community health worker provides: } \\
\text { - case management support, referrals to community- } \\
\text { based housing, education, and employment support; } \\
\text { - medical and social service navigation (accompanying } \\
\text { patients to pharmacies, social services, medical and } \\
\text { behavioral health appointments; } \\
\text { - chronic disease self-management support (home visit } \\
\text { for health education and medication adherence } \\
\text { support). }\end{array}$ & $\begin{array}{l}\text { The program utilized the existing } \\
\text { resources in the community } \\
\text { health center. The additional } \\
\text { costs included the salary of } \\
\text { community health worker and } \\
\text { time of supervision. }\end{array}$ \\
\hline $\begin{array}{l}\text { Wohl, 2011/USA } \\
\text { [37] }\end{array}$ & $\mathrm{RCT}$ & $\begin{array}{l}\text { Sample size: } 89 \text { (43 vs } \\
\text { 46) } \\
\text { Age: not reported. } \\
\text { Sex (female): } 23.3 \% \text { vs } \\
30.4 \% \\
\text { Patients: Individuals with } \\
\text { HIV released from prison } \\
\text { Setting: community } \\
\text { settings }\end{array}$ & $\begin{array}{l}\text { Formerly incarcerated HIV } \\
\text { patients }\end{array}$ & $\begin{array}{l}\text { Bridge case management: } \\
\text { - training of case managers prior to start working with } \\
\text { incarcerated patients (focus on the identification of the } \\
\text { talents, resources, goals in non-judgmental } \\
\text { environment); } \\
\text { - case managers were well aware of the services } \\
\text { available in their home and neighboring counties; } \\
\text { - regular meeting with incarcerated people prior to and } \\
\text { after release to identify medical and non-medical } \\
\text { needs; } \\
\text { - development of care plan including housing, } \\
\text { employment, medical care, substance abuse } \\
\text { counseling; } \\
\text { - transition to community case management and local } \\
\text { services after } 6 \text { months of follow-up; } \\
\text { - caseload of } 15 \text { clients per patient }\end{array}$ & \\
\hline $\begin{array}{l}\text { Dorr, 2008/USA } \\
\text { [49] }\end{array}$ & $\mathrm{RCT}$ & $\begin{array}{l}\text { Sample size: } 3,432 \text { ( } 1,144 \\
\text { vs 2,288) } \\
\text { Age (mean): } 76.2 \pm 7.2 \text { vs } \\
76.2 \pm 7.1 \\
\text { Sex (female): } 64.6 \% \text { vs } \\
64.6 \% \\
\text { Patients: Elderly patients } \\
\text { with chronic diseases } \\
\text { Setting: primary care }\end{array}$ & $\begin{array}{l}\text { Elderly patients with chronic } \\
\text { diseases: diabetes, depression, } \\
\text { hypertension, congestive heart } \\
\text { failure }\end{array}$ & $\begin{array}{l}\text { Care Management Plus: } \\
\text { - training of care managers (nurses) on care for seniors, } \\
\text { caregivers, chronic disease assessment, care standards; } \\
\text { - integration of the information technology tools } \\
\text { (structured protocols, guidelines, tracking database) } \\
\text { and electronic health record system in primary care } \\
\text { facilities; } \\
\text { - placement of care managers in primary care facilities; } \\
\text { - referral of patients with chronic care needs by PCPs to } \\
\text { care managers for assessment and enrolment in care } \\
\text { management services. }\end{array}$ & \\
\hline $\begin{array}{l}\text { Sylvia, 2008/ } \\
\text { USA [39] }\end{array}$ & NRS & $\begin{array}{l}\text { Sample size: } 127 \text { (62 vs } \\
65 \text { ) } \\
\text { Age (mean): } 74.1 \text { vs } 75.8 \\
\text { Sex (female): } 60.3 \% \text { vs } \\
47.7 \%\end{array}$ & $\begin{array}{l}\text { Elderly patients with chronic } \\
\text { diseases congestive heart } \\
\text { failure, hypertension, diabetes, } \\
\text { dementia, depression }\end{array}$ & $\begin{array}{l}\text { Guided Care: } \\
\text { Trained registered nurses working in primary care } \\
\text { practices, in close collaboration with PCPs (1 nurse per } 2 \\
\text { PCPs): } \\
\text { - assess patient and caregiver needs; } \\
\text { - develop an individualized care plan; } \\
\text { - promote patient self-management; }\end{array}$ & $\begin{array}{l}\text { Lower insurance expenditures } \\
(p=0.35)\end{array}$ \\
\hline
\end{tabular}


Table 1 Description of included studies (Continued)

\begin{tabular}{|c|c|c|c|c|}
\hline & & $\begin{array}{l}\text { Patients: High risk } \\
\text { elderly patients with } \\
\text { chronic diseases } \\
\text { Setting: primary care }\end{array}$ & & $\begin{array}{l}\text { - monitor patient's condition; } \\
\text { - coordinate transitions between healthcare services; } \\
\text { - facilitate access to community resources. }\end{array}$ \\
\hline $\begin{array}{l}\text { Gravelle, 2007/ } \\
\text { UK [60] }\end{array}$ & NRS & $\begin{array}{l}\text { Sample size: } 64 \\
\text { intervention primary } \\
\text { care practices } \\
\text { Age: not reported. } \\
\text { Patients: Elderly patients } \\
\text { ( } \geq 65 \text { years old) and a } \\
\text { history of emergency } \\
\text { admission } \\
\text { Setting: primary care }\end{array}$ & $\begin{array}{l}\text { Elderly patients at high risk of } \\
\text { emergency admission }\end{array}$ & $\begin{array}{l}\text { Case management: } \\
\text { - development of individualized care plan by the nurse } \\
\text { practitioners in collaboration with PCP; } \\
\text { - coordination of services to prevent fragmentation of } \\
\text { services; } \\
\text { - arrangement of access to community-based services. }\end{array}$ \\
\hline $\begin{array}{l}\text { Horwitz, 2005/ } \\
\text { USA [40] }\end{array}$ & $\mathrm{RCT}$ & $\begin{array}{l}\text { Sample size: } 230 \text { (121 vs } \\
\text { 109) } \\
\text { Age (mean): } 51.2 \% \text { vs } \\
50.5 \% \text { (less than } \\
30 \text { years old) } \\
\text { Patients: Uninsured } \\
\text { population } \\
\text { Setting: primary care }\end{array}$ & $\begin{array}{l}\text { Uninsured patients (except } \\
\text { substance abuse and mental } \\
\text { health issues) }\end{array}$ & $\begin{array}{l}\text { The Community Access Program: } \\
\text { - identification of uninsured patients before discharge } \\
\text { from the hospital who don't have a PCP; } \\
\text { - assistance with enrolment to one of four PCP; } \\
\text { - faxing the patient data to a case managers of the } \\
\text { primary care facility; } \\
\text { - case managers contacted the patients to arrange an } \\
\text { appointment. }\end{array}$ \\
\hline $\begin{array}{l}\text { Palfrey, 2002/ } \\
\text { USA [32] }\end{array}$ & NRS & $\begin{array}{l}\text { Sample size: } 267 \\
\text { (150 vs } 117) \\
\text { Age (0-5): } 56 \% \text { vs } \\
55.6 \% \\
\text { Sex (female): } 33.3 \% \text { vs } \\
33.3 \% \\
\text { Patients: Children with } \\
\text { special health care } \\
\text { needs } \\
\text { Setting: primary care }\end{array}$ & $\begin{array}{l}\text { Children with special health } \\
\text { care needs }\end{array}$ & $\begin{array}{l}\text { Pediatric Medical Home: } \\
\text { - designation of a pediatric nurse practitioner (PNP); } \\
\text { - designation of a lead PCP; } \\
\text { - arrangement of the schedule for the PNP ( } 8 \text { h per } \\
\text { week devoted to the management of children with } \\
\text { special needs) by the lead physician; } \\
\text { - in-home follow-up by the PNP; } \\
\text { - assistance with appointments and medication supply; } \\
\text { - development of the individualized health plan; } \\
\text { - sharing of the health plan and evolution of the } \\
\text { condition with specialists; } \\
\text { - participation of a local parent consultant. }\end{array}$ \\
\hline $\begin{array}{l}\text { Farmer, 2005/ } \\
\text { USA [27] }\end{array}$ & NRS & $\begin{array}{l}\text { Sample size: } 102 \text { ( } 51 \text { vs } \\
\text { 51) } \\
\text { Age: } 7.4 \pm 5.1 \\
\text { Participants: Children } \\
\text { with special health care } \\
\text { needs } \\
\text { Setting: primary care }\end{array}$ & $\begin{array}{l}\text { Children with special health } \\
\text { care needs (mental and } \\
\text { neurological disorders, } \\
\text { congenital anomalies) }\end{array}$ & $\begin{array}{l}\text { Medical home: } \\
\text { - delivery of care by PCP, nurse practitioner, a parent } \\
\text { consultant; } \\
\text { - nurse practitioner provides: a home visit to conduct } \\
\text { comprehensive assessment of medical and non- } \\
\text { medical needs, a personalized letter describing health } \\
\text { and services available to meet these needs, an individ- } \\
\text { ualized health plan for the child, at least } 1 \text { follow-up; } \\
\text { - nurse practitioner acted as consultant for } 3 \text { primary } \\
\text { care practices; }\end{array}$ \\
\hline
\end{tabular}

Reduction in average cost of an emergency room visit 
Table 1 Description of included studies (Continued)

Counsell, 2007/ RCT USA [38]

Landi, 2001/Italy NRS [63]

Callahan, 2006/ RCT USA [51]
Sample size: 120 (59 vs Patients with mental disorders: 61) (female): $0 \%$ vs

$1.6 \%$

Patients: Patients with

mental disorders

Setting: primary care

Sample size: 951 (474 vs Low-income seniors (less than 477) Age (mean): $71.8 \pm 5.6$ vs Poverty) with geriatric $71.6 \pm 5.8 \quad$ conditions such as difficulty Sex (female): $75.5 \%$ vs walking, falls, pain, urinary $76.5 \%$ incontinence, depression Patients: Low-income vision and hearing problems, seniors dementia

Setting: primary care

Sample size: 1204

(before-after)

Age (mean): $77.4 \pm 9.7$

Sex (female): $58.5 \%$

Patients: Frail older

people

Setting: primary care

Frail older people

disorder, substance abuse

- nurse practitioner interacts regularly with referring physicians and a designated nurse at each primary care practice;

medical care was provided by these practices:

- a web-site was developed to ease access to additiona supports and recourses by families and physicians.

integrated care:

Integrated mental health service in the primary care (a multidisciplinary team of a nurse practitioner, PCP, a nurse case manager, physicians in the psychiatry and mental health clinics):

- supervision of the nurse practitioner (providing basic

medical care) by the primary care provider;

- primary care provider is a liaison of primary and specialized services;

- the nurse provides education, preventive services,

follow-up (telephone, e-mail, face-to-face), schedules an appointment;

the nurse practitioner serves as a liaison of 3 mental health teams.

Geriatric Resources for Assessment and Care of Elders (GRACE):

nume comprehensive geriatric assessment by a nurse/social worker;

- development of individualized care plan by a

multidisciplinary team (a geriatrician, pharmacist, physical therapist, mental health social worker, community-based services representatives):

regular meeting of the multidisciplinary team and $\mathrm{PCP}$. - ongoing support via en electronic medical records and web-based tracking system.

Home care program:

- development of the community Geriatric Evaluation Unit ("a single enter center") consisting of a geriatrician, a social worker, a physiotherapist, nurses jointly with a PCP;

- initial and follow-up assessments by case manager (a nurse)

- coordination of services delivery;

- facilitation of access to community-based services; - PCP involved directly in care planning, case finding and emergency situations.

Sample size: 153 (84 vs Patients with dementia living 69)

Patients with dementia living Collaborative care model

- development of individualized care plan for the

- regular assessment of patients' condition

$77.7 \pm 5.7$

Sex (female): $46.4 \%$ vs

$39.1 \%$ patient-caregiver dyad in the community

- medication management by PCP,
$27 \%$ cost reduction with an estimated saving of $\$ 1,200$ for each patient

$\$ 1000$ annual cost of the case manager per patient (75 patients per year) 
Table 1 Description of included studies (Continued)

Patients: dementia

patients

Setting: primary care

Continuity of care via arrangement for follow-up

\begin{tabular}{|c|c|c|}
\hline $\begin{array}{l}\text { Sin, 2004/ } \\
\text { Canada [57] }\end{array}$ & NRS & $\begin{array}{l}\text { Sample size: } 125 \\
\text { (63 vs } 62) \\
\text { Age: } 22.5 \pm 13.7 \text { vs } 22.7 \\
\pm 12.6 \\
\text { Sex (female): } 46 \% \text { vs } \\
74 \% \\
\text { Patients: Patients with } \\
\text { asthma } \\
\text { Setting: primary care }\end{array}$ \\
\hline $\begin{array}{l}\text { DeHaven, 2012/ } \\
\text { USA [48] }\end{array}$ & NRS & $\begin{array}{l}\text { Sample size: } 574 \\
\text { ( } 265 \text { vs } 309) \\
\text { Age: } 35.7 \pm 12 \text { vs } 35 \pm \\
12.1 \\
\text { Participants: Uninsured } \\
\text { adults } \\
\text { Setting: primary care }\end{array}$ \\
\hline \multicolumn{3}{|c|}{ Institution incentives ${ }^{a}$} \\
\hline $\begin{array}{l}\text { Addink, 2011/ } \\
\text { UK [58] }\end{array}$ & NRS & $\begin{array}{l}\text { Sample size: } 24 \text { practice } \\
\text { in three local primary } \\
\text { care trusts } \\
\text { Age: not reported. } \\
\text { Participants: Ethnic } \\
\text { minority. } \\
\text { Setting: primary care }\end{array}$ \\
\hline $\begin{array}{l}\text { Tan, 2012/New } \\
\text { Zealand [66] }\end{array}$ & $\begin{array}{l}\text { Mixed methods study } \\
\text { (convergent parallel } \\
\text { design) }\end{array}$ & $\begin{array}{l}\text { Sample size: the whole } \\
\text { population } \\
\text { Age: not reported. } \\
\text { Patients: Ethnic and } \\
\text { refugee communities, } \\
\text { young people } \\
\text { Setting: primary care }\end{array}$ \\
\hline
\end{tabular}

setting: primary care
- weekly review of care and adherence to guidelines by multidisciplinary team (geriatric nurse practitioner, $\mathrm{PCP}$ geriatrician, geriatric psychiatrist, psychologist)

- monitoring of health condition and communication of healthcare professionals via web-based system.

Patients with asthma

Enhanced care:

-follow-up appointment with PCP within 4 weeks of discharge;

- a study coordinator makes an appointment on behalf of the patient

- in case a patient does not have a PCP, he is offered to choose from a list of physicians willing to accept new patients;

- a reminder telephone call 1 or 2 days before the scheduled follow-up visit;

ninsured low-income work-

ing individuals

\section{Project Access Dallas:}

- monthly meeting with a community health worker; - patients assigned to a PCP.

- referral to the specialist if needed

- pharmacy benefits ( $\$ 750$ a year);

- PCPs and specialists donated their services depending on their capacity

Patients from ethnic minority groups (non-white ethnicity)

Prioritized population: high deprivation, Maori, Pacific communities, refugees, young people (community health workers, additional nurses and
Pay for performance scheme:

Primary care practices received payment according to their performance based on the reporting of their

patients.

$£ 36$ million received for participation;

£72 million received based on the positive responses of patients ( $£ 1.37$ per highly satisfied registered patient)

Primary care framework:

Sustained and targeted investments over five years in: - development of service delivery for equitable access outreach services, youth service);

- engagement of healthcare professionals to develop these services;

- development of health approaches in collaboration with ethnic groups (e.g., iwi):

information sharing across the range of support services:

- building on intersectoral relationships; 
Table 1 Description of included studies (Continued)

RCT Randomized Controlled Trial, NRS Non-Randomized Study, NS Non-significant

${ }^{a}$ Financial interventions according to the EPOC classification

support of leadership by clinicians in more

Feinglass, 2014/ NRS

USA [28]

Capitation $^{\mathrm{a}}$

Davidoff, 2008/ NRS

USA $[25,67]$
Sample size: 293

(138 vs 158)

Age (45-64): $48.8 \%$ vs

$58.8 \%$

Sex (female): $68 \%$ vs

$60 \%$

Participants: Uninsure

adults

Setting: primary care

Sample size: 574

(265 vs 309)

Age: $2-17$

Participants: Children

with chronic health

conditions

Setting: primary care
Uninsured adults with a household income below $200 \%$ of Federal Poverty Level.

\section{Children with common}

chronic health conditions such

as attention deficit disorder,

mental retardation, Down

syndrome, asthma, cerebra

palsy, sickle cell anemia,

muscular dystrophy, autism

congenital or other hear

diseases, diabetes.
Decrease of amount of payment/

County Health Care program (Access DuPage):

assigns patients to PCPs;

copayment for a visit $(p<0.0001)$

- pays a small capitated fee to primary care clinics and

PCPs while most of funding comes from county

hospitals, county government, and foundations;

- coordinates purchase of medications with small

enrollee copays;

- handles applications for Drug Assistance Programs

which provides enrollees with medications.

Primary care case management:

- PCPs are paid for care coordination to serve as

"gatekeeper" for referrals to specialty services;

- care provided by PCPs is focused on early intervention,

appropriateness, and coordination. 
Table 2 Vulnerability context

\begin{tabular}{|c|c|}
\hline Vulnerability context & Included studies, n (\%) \\
\hline \multicolumn{2}{|l|}{ Socioeconomically disadvantaged $(n=14)$} \\
\hline Uninsured & $11(28 \%)$ \\
\hline Immigrants & $1(2 \%)$ \\
\hline Formerly incarcerated & $2(5 \%)$ \\
\hline Racial/ethnic minority $(n=1)$ & $1(2 \%)$ \\
\hline $\begin{array}{l}\text { First Nations (Maori, Alaska Native, American } \\
\text { Indian, Pacific) }(n=4)\end{array}$ & $4(10 \%)$ \\
\hline \multicolumn{2}{|l|}{ Chronic diseases $(n=25)$} \\
\hline $\begin{array}{l}\text { Multi-morbidity (chronic heart failure, chronic } \\
\text { obstructive pulmonary diseases, hypertension, } \\
\text { dyslipidemia, diabetes, obesity) }\end{array}$ & $5(13 \%)$ \\
\hline $\begin{array}{l}\text { Multi-morbidity non-specified (e.g., functional } \\
\text { decline, frailty) }\end{array}$ & $5(13 \%)$ \\
\hline $\begin{array}{l}\text { Geriatric conditions (difficulty walking/falls, } \\
\text { urinary incontinence, vision/hearing problems, } \\
\text { dementia) }\end{array}$ & $(5 \%)$ \\
\hline $\begin{array}{l}\text { Mental diseases (chronic psychosis, depression, } \\
\text { anxiety, bipolar disorder, schizophrenia, } \\
\text { personality disorders, panic disorder) }\end{array}$ & $5(13 \%)$ \\
\hline Diabetes & $2(5 \%)$ \\
\hline Asthma & $1(2 \%)$ \\
\hline HIV & $2(5 \%)$ \\
\hline $\begin{array}{l}\text { Congenital conditions (mental retardation, } \\
\text { Down syndrome, cerebral palsy, muscular } \\
\text { dystrophy, autism) }\end{array}$ & $3(8 \%)$ \\
\hline Elderly with chronic diseases $(n=11)$ & $11(28 \%)$ \\
\hline Children with chronic diseases $(n=5)$ & $5(13 \%)$ \\
\hline
\end{tabular}

\section{Clinical multidisciplinary team}

This organizational intervention is based on two approaches - creation of a team with healthcare professionals from multiple disciplines $[45,50]$ or addition of a new member to the existing team (i.e., local indigenous health workers [62] or ethnic group representative [44], a dietitian [52], a nurse practitioner in a team of mental health professionals [54]).

\section{Continuity of care via arrangement for follow-up}

This organizational intervention is based on close follow-up either post discharge [57] or on a predefined frequency [48] to ensure timely access to services.

\section{Revision of professional role}

A new role has been assigned to provide a different care in one study (a social worker of local ethnicity trained in skin infection recognition) [61].

\section{Institution incentive and capitation}

These organizational interventions are based on financial incentives to provide a financial reward for performing specific action $[28,58,66]$ or to award a certain amount per patient seen $[25,67]$.

\section{Pattern 'dimension-outcome'}

Regarding access dimensions and outcomes, the characteristics of studies on local/regional interventions and state/national interventions are described in Appendix 2 and 3, respectively. The dimension-outcome patterns are summarized in Table 3 . The pattern analysis revealed one pattern. Results of the 10 studies on interventions classified as 'Formal integration of services' showed that in almost all cases these interventions were associated with three dimensions of access (approachability, availability and affordability) and reduction of hospitalizations (four/four studies), emergency department admissions (six/six studies), and unmet healthcare needs (five/six studies) (number of studies with a positive outcome/number of studies assessing this outcome). Various research designs were used: non-randomized $(n=7)$, randomized controlled $(n=1)$, quantitative descriptive $(n=1)$, and mixed methods $(n=1)$. These 10 studies were reported across 12 papers (Table 1) [26, 29, 31, 33, 34, 41, 42, 46, 53, 56, 64, 65].

A possible subpattern has been found in the category of organizational interventions "Continuity of care via case management": reduction of unmet health care needs in the studies associated with two dimensions of access - approachability and availability [27, 32, 36]. Non-randomized $(n=2)$ and randomized controlled ( $n=1)$ designs were used. However, considering a limited number of identified studies a conclusion on the 'dimension-outcome' pattern cannot be made.

\section{Discussion}

This scoping review included 39 studies of organizational interventions aimed at improving access to primary care for vulnerable populations (patients with chronic conditions and socioeconomically disadvantaged people), which have evaluated the impact of these interventions on hospitalization, emergency department admission, or unmet health care needs. Results revealed one 'dimensionoutcome' pattern: the formal integration of services in which the reduction of hospitalization, emergency department admission and unmet health care needs was associated with three dimensions of access (approachability, availability and affordability), specifically for patients with low income or uninsured, patients with mental health problems, and elderly patients with multiple chronic conditions.

Formal integration of services means bringing all primary medical and social service providers together, typically with mental health service professionals, to meet the needs of the disadvantaged population. This is similar to 'seamless care' in inter-professional education (transversal 
Table 3 Pattern dimension-outcome

\begin{tabular}{|c|c|c|c|c|c|}
\hline \multirow[t]{2}{*}{ Organizational intervention } & \multirow{2}{*}{$\begin{array}{l}\text { Number of } \\
\text { studies }\end{array}$} & \multicolumn{3}{|c|}{ Outcomes $^{a}$} & \multirow{2}{*}{$\begin{array}{l}\text { Pattern 'Dimension } \\
\text { Outcome' }\end{array}$} \\
\hline & & $\downarrow H R$ & $\downarrow$ ED admission & $\downarrow$ Unmet health care needs & \\
\hline Continuity of care via case management & $16^{\mathrm{b}}$ & $8 / 15$ & $7 / 13$ & $3 / 3$ & No \\
\hline Formal integration of services & $10^{c}$ & $4 / 4$ & $6 / 6$ & $5 / 6$ & Yes $^{d}$ \\
\hline Clinical multidisciplinary teams & 6 & $1 / 1$ & $0 / 4$ & $2 / 2$ & No \\
\hline Continuity of care via arrangement for follow-up & 2 & $1 / 1$ & $1 / 1$ & - & No \\
\hline Revision of professional roles & 1 & - & - & $1 / 1$ & No \\
\hline Institution incentives & 3 & $1 / 2$ & $0 / 1$ & $1 / 2$ & No \\
\hline Capitation & 1 & - & $1 / 1$ & $0 / 1$ & No \\
\hline
\end{tabular}

HR hospitalisation rate, ED emergency department, RCT Randomized Controlled Trial, NRS Non-Randomized Study

${ }^{a}$ Numerator: Number of studies with a positive outcome; Denominator: Number of studies assessing the outcome

${ }^{\mathrm{b}} 9$ RCTs and 7 NRSs

${ }^{9} 7 \mathrm{NRS}, 1$ RCT, 1 quantitative descriptive and 1 mixed methods study

${ }^{\mathrm{d}}$ Associated with three dimensions of access: approachability, availability and affordability

integration) and inter-organizational pharmaceutical care (vertical integration) where students from multiple health disciplines, hospital and community pharmacists, formally do teamwork together, respectively $[68,69]$. This also refers to 'shared care' or 'collaborative care' in mental health for instance, which consists of "a structured system for achieving integration of care across multiple autonomous providers and services with both primary and secondary care practitioners contributing to elements of a patient's overall package of care" where "mental health experts work with first-line care providers in the delivery of mental health promotion, illness prevention, detection and treatment of mental illnesses, as well as rehabilitation and recovery support [70, 71]." For example, in the identified intervention studies formal integration was mainly done through teams including both primary care physicians and specialized health service providers in mental health, alcohol and substance abuse, and home care programs. An illustration of formal integration is a medical home (called Family Medicine Groups in Quebec or Family Health Teams in Ontario, Canada) when parents in situation of vulnerability are informed about all available services (approachability) to get them in time (availability) and free (affordability) including transcultural child mental health support if needed [72].

Our results indicate that the most commonly evaluated dimensions of access were approachability, availability and affordability for interventions targeting vulnerable populations. The most commonly evaluated type of intervention was continuity of care via case management; this type was not associated with a reduction of hospitalization and emergency department admission, although we did find in a recent systematic review that this type of intervention is effective for elderly patients with dementia $[16,17]$.

In addition, our results suggest a research gap in looking at vulnerability and access to primary care services from a patient perspective. Specifically, a paucity of research regarding reduction of hospitalization, emergency department admission, and unmet service needs outcomes with regard to five types of intervention (clinical multidisciplinary teams, revision of professional role, continuity of care via arrangement for follow-up, institution incentive, and capitation). Moreover, this work suggests a need for more research on these outcomes as well as the acceptability and appropriateness dimensions of access.

Ultimately, patients' and caregivers' ability to identify healthcare needs, and to know where to access primary care, as well as the ability to engage with care in order to receive what is actually appropriate could be the crucial gaps in access for vulnerable populations in certain contexts. This illustrates the challenge of embedding patient's self-efficacy in policies. This scoping review suggests it can be easier to target structural resources and clinical behaviors (supply-side perspective) to adapt services to the needs, expectations and abilities of patients, rather than to empower patients and caregivers to more broadly engage in care access, which is what the Australian-Canadian IMPACT program is seeking to accomplish.

While only one 'dimension-outcome' pattern was found in this review, the limited number of included studies on patients in situation of vulnerability and the theory-driven approach may have precluded finding others. For example, we found few studies on the three outcomes of interest outside the formal integration of services and case management. This might reflect the fact that few innovations have been evaluated or published yet. For instance, several organizational innovations have been put in place in OECD countries to improve access to primary care (i.e., advanced access) [73]. Although numerous articles describe primary care organizational innovations for vulnerable populations, few report on the evaluation of these innovations. While three main databases were searched, subsequent systematic review may include an exhaustive search of evidence in 
multiple databases (including management databases, e.g., Health Business Elite), the grey literature, and citation tracking (e.g., in Scopus) with selection of bibliographic records and full-texts by two independent reviewers. However, the broad criteria of our search make it less likely that important articles were missed. Another implication for future review is derived from the focus of this scoping review on three outcomes and the limitation of the EPOC classification. Studies on other outcomes (i.e., health status) were excluded, while they can be considered. The EPOC classification of interventions pointed to key components of interventions, while other components can be considered. Various intervention elements appeared across different EPOC categories, suggesting the need for an inductive and finer grained typology of interventions to inform future practice. For example, the above-mentioned IMPACT program, led by the last four co-authors, is developing an inductive taxonomy of organizational interventions for improving access to primary care for vulnerable populations. This taxonomy could be useful for planning future research and reviews, improving practice and developing policies.

\section{Conclusion}

While there appears to be a limited number of published research studies about organizational interventions aimed at improving access to primary care for vulnerable populations, our scoping review showed that there are enough studies for a future systematic review to test the following hypothesis: formal integration of services (increased approachability, availability and affordability of primary care services) could be associated with a reduction of hospitalization, emergency room admission and unmet health care needs. Not surprisingly, our results also suggest approachability, availability and affordability could play an important role in access to care for vulnerable populations. Considering that this scoping review included all types of evidence, and suggests access to primary health care services for vulnerable populations could be improved by formal integration of services, future research can provide stronger evidence on finer grained types of interventions and other types of outcome.

\section{Appendix 1}

\section{Example of search strategy in Embase database}

1. translational research/(5528)

2. integrated health care system/(6588)

3. Case Management/(7314)

4. Knowledge Management/(762)

5. exp quality control/(220922)

6. health care quality/(153298)
7. Organi?ational innovation*.tw. (71)

8. innovat".ti. (14842)

9. Organi?ational change*.tw. (1807)

10. organi?ational model*.tw. (548)

11. (diffusion adj2 innovation*).tw. (504)

12. Integrated delivery system*.tw. (569)

13. Integrated Health Care System*.tw. (325)

14. Integrated Health* System*.tw. (544)

15. (program or programs or programme or programmes).tw. (468596)

16. medical care team*.tw. (56)

17. interdisciplinary health team*.tw. (11)

18. healthcare team*.tw. (1537)

19. health care team*.tw. (2704)

20. case management.tw. (7055)

21. managed care.tw. (15501)

22. knowledge management.tw. (838)

23. healthcare quality.tw. (1068)

24. health care quality.tw. (1756)

25. quality of health care.tw. (4484)

26. quality of healthcare.tw. (1334)

27. quality management.tw. (5531)

28. quality assurance.tw. (17475)

29. case coordination.tw. (25)

30. (intervention or interventions).tw. (582350)

31. multidisciplinary team*.tw. (12026)

32. or/1-31 (1321868)

33. health care access/(34233)

34. health care availability/(7450)

35. Healthcare Disparity/(5959)

36. exp patient attitude/(217912)

37. (availab* adj2 (healthcare or health care or health service $\left.\left.^{*}\right)\right)$.tw. (1393)

38. (access ${ }^{*}$ adj2 (healthcare or health care or health service $\left.\left.^{*}\right)\right)$.tw. (9122)

39. access $^{*}$.ti. (40638)

40. program* accessibility.tw. (20)

41. program* availability.tw. (62)

42. affordability.tw. (2214)

43. approachability.tw. (103)

44. appropriateness.tw. (13616)

45. or/33-44 (311948)

46. 32 and 45 (86444)

47. exp child health care/(47406)

48. exp community care/(63087)

49. Mental Health Services/(31280)

50. exp Primary Health Care/(86682)

51. General Practice/(43336)

52. child health service*.tw. (444)

53. infant health service*.tw. (16)

54. community nurs*.tw. (1833)

55. community mental health service*.tw. (588)

56. community health service ${ }^{*}$.tw. (551)

57. community pharmac* service*.tw. (123) 
58. maternal health service*.tw. (246)

59. preventive health service*.tw. (361)

60. (senior center* or senior centre* ${ }^{*}$ ).tw. (462)

61. (center* for the aged or centre* for the aged).tw. (334)

62. primary care.tw. (76389)

63. primary health care.tw. (11687)

64. primary healthcare.tw. (2676)

65. general practice.tw. (21225)

66. family practice.tw. (3694)

67. family medicine.tw. (6162)

68. or/47-67 (285192)

69.46 and 68 (15001)

70. Vulnerable Population/(6013)

71. Poverty/(23599)

72. Unemployment/(7459)

73. Homelessness/(5938)

74. chronic disease/(97466)

75. mental disease/(118256)

76. exp *mental disease/(664947)

77. exp *aged/(16069)

78. frail elderly/(5142)

79. very elderly/(9994)

80. Minority Group/(8274)

81. Disabled Person/(12980)

82. exp "Drug Use"/(150974)

83. medically uninsured/(315)

84. illegal immigrant/(131)

85. immigrant/(8277)

86. indigent/(329)

87 . lowest income grouup/(0)

88. medically underserved/(262)

89. refugee/(5352)

90. exp Terminally Ill patient/(4703)

91. vulnerab*.tw. (76118)

92. poverty.tw. (13629)

93. high risk population*.tw. (8227)

94. high risk patient".tw. (28251)

95. complex patient".tw. (1884)

96. complex need*.tw. (851)

97. sensitive population*.tw. (315)

98. disadvantaged.tw. (6913)

99. (underserved or under served).tw. (5638)

100. indigen*.tw. (18928)

101. tribes.tw. (2017)

102. native*.tw. (124764)

103. aboriginal*.tw. (5424)

104. low income.tw. (17600)

105. unemploy*.tw. (10051)

106. underemploy*.tw. (179)

107. homeless *.tw. (5781)

108. (street people or street person*).tw. (12)

109. social* stigma*.tw. (1141)

110. social" isolat*.tw. (4447) 111.inequalit*.tw. (13899)

112. uninsured.tw. (5190)

113. underinsured.tw. (459)

114. uneducated.tw. (402)

115. low educat*.tw. (4366)

116. poorly educated.tw. (260)

117. illitera*.tw. (3098)

118. chronic disease*.tw. (39799)

119. chronic* ill*.tw. (13506)

120. chronic condition*.tw. (10227)

121. aged.tw. (351635)

122. old.tw. (694632)

123. older.tw. (266367)

124. elderly.tw. (162147)

125. frail*.tw. (10361)

126. (senior or seniors).tw. (24681)

127. functional* impair*.tw. (12914)

128. disabled.tw. (13707)

129. disability.tw. (95888)

130. disabilities.tw. (28088)

131. handicapped.tw. (2633)

132. physically challenged.tw. (54)

133. mentally challenged.tw. (89)

134. mental disorder*.tw. (23602)

135. mental* ill*.tw. (21844)

136. psychiatric diagnos*.tw. (6839)

137. drug use ${ }^{*}$.tw. (42628)

138. drug abuse*.tw. (12151)

139. drug addict*.tw. (6598)

140. drug dependen*.tw. (4120)

141. drug habit*.tw. (69)

142. "substance use".tw. (19197)

143. substance dependen*.tw. (2410)

144. substance addict*.tw. (285)

145. uninsured.tw. (5190)

146. underinsured.tw. (459)

147. terminal* ill*.tw. (4662)

148. minority.tw. (38757)

149. minorities.tw. (6698)

150. immigra*.tw. (19128)

151. foreigner*.tw. (952)

152. refugee $*$.tw. (4336)

153. or/70-152 (2572418)

154.69 and 153 (7631)

155. limit 154 to $\mathrm{yr}=$ "2000 -Current" (7118)

156. limit 155 to (english or french) (6891)

157. qualitative research*.mp. (29502)

158. qualitative stud*.mp. (18918)

159. action research.mp. (2607)

160. Participatory Research/(1916)

161. participatory research.mp. (3107)

162. case stud*.mp. (68678)

163. ethno*.mp. (67315)

164. grounded theory.mp. (6560) 
165. phenomeno*.mp. (137337)

166. Narrative/(2274)

167. narrative*.mp. (16468)

168. biograph*.mp. (4728)

169. Autobiograph*.mp. (3202)

170. documentar*.mp. (1411)

171. qualitative synthes".mp. (229)

172. active feedback.mp. (106)

173. conversation*.mp. (11040)

174. discourse".mp. (9173)

175. thematic.mp. (10376)

176. qualitative data.mp. (6953)

177. key informant".mp. (3676)

178. focus group".mp. (25043)

179. case report*.mp. (1137960)

180. exp Interview/(123867)

181.interview*.mp. (240740)

182. exp Observational method/(1826)

183. observer".mp. (52777)

184. visual data.mp. (249)

185. (audio adj record*).mp. (2581)

186. Cultural Anthropology/(32392)

187. experience*.mp. (670612)

188. or/157-187 (2271697)

189. exp clinical study/(4260567)

190. exp Methodology/(2712060)

191. randomization/(54544)

192. Placebos/(185259)

193. Crossover procedure/(35159)

194. or/189-193 (5940545)

195. (clinic* adj25 trial*).mp. (966368)

196. random*.mp. (862922)

197. control".mp. (5237933)

198. (latin adj square).mp. (2318)

199. placebo".mp. (243987)

200. or/195-199 (5877623)

201. exp Comparative Study/(666277)

202. comparative stud".mp. (469566)

203. Validation Study/(44621)

204. validation stud".mp. (50401)

205. evaluation research/(1614)

206. evaluation stud".mp. (5068)

207. Follow-Up/(685736)

208. followup.mp. (21000)

209. follow-up.mp. (902021)

210. cross over.mp. (14288)

211. crossover.mp. (50503)

212. prospective*.mp. (548205)

213. volunteer".mp. (132028)

214. or/201-213 (2089573)

215. singl*.mp. (1081892)

216. doubl".mp. (392712)

217.trebl*.mp. (253)

218. tripl".mp. (76252)
219. or/215-218 (1456962)

220. mask*.mp. (51854)

221. blind*.mp. (236161)

222.220 or 221 (284003)

223. 219 and 222 (164051)

224.194 or 200 or 214 or 223 (9418632)

225. exp Health Survey/(140568)

226. Health Care Survey/(5933)

227. exp Risk/(1311750)

228. exp Incidence/(231106)

229. exp Prevalence/(360569)

230. exp Mortality/(512165)

231. cohort*.mp. (395294)

232. case-control.mp. (122486)

233. cross sectional.mp. (214289)

234. (health* adj2 survey*).mp. (155311)

235. risk.mp. (1871315)

236. incidence.mp. (563598)

237. prevalence.mp. (512194)

238. mortality.tw. (486678)

239. "case series".mp. (43403)

240. "time series".mp. (24993)

241. "before and after".mp. (171898)

242. prognos*.mp. (514923)

243. predict".mp. (1017431)

244. course ${ }^{*} . \mathrm{mp}$. (614624)

245. or/225-244 (4558876)

246. (mixed adj5 method*).mp. (9599)

247. multimethod*.mp. (1003)

248. (multiple adj5 method*).mp. (22707)

249. or/246-248 (33153)

250. qualitative.mp. (135948)

251. Qualitative Research/(23741)

252. quantitative.mp. (442547)

253. or 251 (135948)

254.252 and 253 (48559)

255.249 or 254 (79725)

256.188 or 224 or 245 or 255 (10841719)

257.256 not (letter/or editorial/) (10370545)

258.257 not (animal not human).sh. (10070426)

259.156 and 258 (6064)

260. limit 259 to embase (4439) 


\section{Appendix 2}

Table 4 Characteristics of included studies (local/regional intervention): Access dimension and outcome

\begin{tabular}{|c|c|c|c|c|c|c|c|c|c|}
\hline \multirow[t]{2}{*}{ Study ID } & \multicolumn{5}{|c|}{ Dimensions of access of primary care services } & \multirow{2}{*}{$\begin{array}{l}\text { Dimensions of ability of } \\
\text { consumers } \\
\text { Ability to (1) Perceive; (2) } \\
\text { Seek; (3) Reach; (4) Pay; } \\
\text { (5) Engage }\end{array}$} & \multicolumn{3}{|l|}{ Outcomes } \\
\hline & Approachability & Acceptability & $\begin{array}{l}\text { Availability and } \\
\text { Accommodation }\end{array}$ & Affordability & Appropriateness & & $\begin{array}{l}\text { Avoidable } \\
\text { hospitalization }\end{array}$ & $\begin{array}{l}\text { Avoidable ED } \\
\text { admission }\end{array}$ & $\begin{array}{l}\text { Unmet health } \\
\text { care needs }\end{array}$ \\
\hline \multicolumn{10}{|c|}{ Revision of professional roles } \\
\hline Gray, 2013 [61] & $\begin{array}{l}\text { Students with } \\
\text { symptoms of } \\
\text { sore throat and } \\
\text { skin infection } \\
\text { were regularly } \\
\text { searched }\end{array}$ & $\begin{array}{l}\text { The social } \\
\text { worker } \\
\text { providing } \\
\text { health care } \\
\text { services was } \\
\text { the same } \\
\text { ethnic group }\end{array}$ & $\begin{array}{l}\text { Health care } \\
\text { services } \\
\text { delivered } \\
\text { directly at } \\
\text { primary school, } \\
\text { at home (for } \\
\text { household } \\
\text { members), } \\
\text { regular phone } \\
\text { contacts. }\end{array}$ & $\begin{array}{l}\text { Free health care } \\
\text { program }\end{array}$ & & $\begin{array}{l}\text { Ability to perceive: } \\
\text { education of parents on } \\
\text { the importance of the } \\
\text { provided services; } \\
\text { Ability to reach: } \\
\text { availability of the health } \\
\text { care program in the } \\
\text { primary school. } \\
\text { Ability to pay: free health } \\
\text { care program }\end{array}$ & & & $\begin{array}{l}\text { Health care } \\
\text { service received } \\
\text { in a timely manner. }\end{array}$ \\
\hline \multicolumn{10}{|c|}{ Clinical multidisciplinary teams } \\
\hline Doey, $2008[54]$ & & & $\begin{array}{l}\text { "One-stop } \\
\text { shopping for } \\
\text { clients" - co- } \\
\text { location of pri- } \\
\text { mary health ser- } \\
\text { vices with } \\
\text { mental care. }\end{array}$ & $\begin{array}{l}\text { Intervention in } \\
\text { public health care } \\
\text { system }\end{array}$ & $\begin{array}{l}\text { Timeliness of } \\
\text { primary health } \\
\text { services delivery } \\
\text { (preventive } \\
\text { measures) }\end{array}$ & & $\begin{array}{l}75 \% \text { decrease } \\
\text { of } \\
\text { hospitalization }\end{array}$ & $\begin{array}{l}-51.6 \% \\
\text { decrease in } \\
\text { the number } \\
\text { of } \\
\text { emergency } \\
\text { visits; } \\
-38 \% \text { never } \\
\text { used } \\
\text { emergency } \\
\text { services. }\end{array}$ & \\
\hline $\begin{array}{l}\text { Crustolo, } 2005 \\
{[52]}\end{array}$ & $\begin{array}{l}\text { Referral to the } \\
\text { dietitian by the } \\
\text { PCP if nutrition- } \\
\text { related prob- } \\
\text { lems were } \\
\text { present }\end{array}$ & & $\begin{array}{l}\text { Location of } \\
\text { dietitian in } \\
\text { primary care. }\end{array}$ & $\begin{array}{l}\text { Intervention in } \\
\text { public health care } \\
\text { system }\end{array}$ & $\begin{array}{l}\text { Intervention was } \\
\text { offered at an early } \\
\text { stage of the } \\
\text { health condition } \\
\text { (e.g., priority to } \\
\text { prevent childhood } \\
\text { obesity). }\end{array}$ & & & & $\begin{array}{l}\text { Patients were } \\
\text { satisfied with: } \\
\text { - length of wait } \\
\text { for appointment; } \\
\text { - getting through } \\
\text { by phone; } \\
\text { - length of time } \\
\text { waiting; } \\
\text { - time spent with } \\
\text { healthcare } \\
\text { professional; } \\
\text { - explanation of } \\
\text { what was done; } \\
\text { - personal manner } \\
\text { of healthcare } \\
\text { professional; } \\
\text { - major health } \\
\text { concerns were } \\
\text { addressed. }\end{array}$ \\
\hline
\end{tabular}


Table 4 Characteristics of included studies (local/regional intervention): Access dimension and outcome (Continued)

\begin{tabular}{|c|c|c|c|c|c|c|c|c|c|}
\hline $\begin{array}{l}\text { McCuloch, } 2000 \\
\text { [45] }\end{array}$ & $\begin{array}{l}\text { Patients } \\
\text { identified } \\
\text { through } \\
\text { diabetes } \\
\text { registers }\end{array}$ & & $\begin{array}{l}\text { Available } \\
\text { assessment by } \\
\text { specialists in } \\
\text { primary care } \\
\text { practice }\end{array}$ & & $\begin{array}{l}\text { Timely assessment } \\
\text { of patients to } \\
\text { avoid } \\
\text { complications } \\
\text { (retinal screening, } \\
\text { screening for } \\
\text { microalbuminuria, } \\
\text { hyperglycemia) }\end{array}$ & & $\begin{array}{l}\text { Decrease by } \\
17 \%\end{array}$ & No difference & \\
\hline $\begin{array}{l}\text { Michelen, } 2006 \\
\text { [44] }\end{array}$ & $\begin{array}{l}\text { Information } \\
\text { about frequent } \\
\text { users of ED ( } 3 \\
\text { or more times } \\
\text { in the past } \\
6 \text { months) was } \\
\text { e-mailed to } \\
\text { healthcare pro- } \\
\text { fessionals who } \\
\text { contacted them } \\
\text { thereafter. }\end{array}$ & $\begin{array}{l}\text { Healthcare } \\
\text { professionals } \\
\text { providing } \\
\text { the } \\
\text { intervention } \\
\text { were from } \\
\text { the same } \\
\text { ethnical } \\
\text { background }\end{array}$ & $\begin{array}{l}\text { Patients living in } \\
\text { three } \\
\text { neighborhoods } \\
\text { (Harlem, } \\
\text { Washington } \\
\text { Heights, } \\
\text { Inwood) were } \\
\text { enrolled }\end{array}$ & & & $\begin{array}{l}\text { Ability to reach: primary } \\
\text { care services available in } \\
\text { the geographic catch } \\
\text { area (neighborhood) of } \\
\text { the intervention. }\end{array}$ & & $\begin{array}{l}\text { Decrease at } \\
3 \text { months ( } p \\
=0.002) \text {, no } \\
\text { difference at } \\
6 \text { month }\end{array}$ & \\
\hline $\begin{array}{l}\text { Driscoll, } 2013 \\
\text { [50] }\end{array}$ & & & & $\begin{array}{l}\text { Payers are Indian } \\
\text { Health Services, } \\
\text { Medicaid/Medicare, } \\
\text { independent } \\
\text { insurers }\end{array}$ & & & & $\begin{array}{l}\text { Decrease }(p \\
<0.001)\end{array}$ & \\
\hline \multicolumn{10}{|c|}{ Formal integration of services } \\
\hline Day, 2006 [65] & & & $\begin{array}{l}\text { Location of } \\
\text { specialized } \\
\text { mental health } \\
\text { services in } \\
\text { primary care } \\
\text { practice. }\end{array}$ & & & & & & $\begin{array}{l}\text { Satisfied with: } \\
\text { - length of wait } \\
\text { prior to the first } \\
\text { appointment } \\
(85.1 \%) ; \\
\text { - location (95.5\%); } \\
\text { - quality of venue } \\
(89.5 \%) \\
\text { - duration of the } \\
\text { appointment } \\
(92.7 \%) ; \\
-94 \% \text { found the } \\
\text { appointment } \\
\text { convenient. }\end{array}$ \\
\hline Garg, 2012 [26] & & & & & $\begin{array}{l}\text { Community } \\
\text { services were } \\
\text { provided } \\
\text { appropriate to the } \\
\text { needs (e.g., } \\
\text { employment to }\end{array}$ & & & & $\begin{array}{l}\text { Reduction of unmet } \\
\text { social needs ( } 50 \% \\
\text { of families enrolled } \\
\text { in at least one } \\
\text { community-based } \\
\text { resources). }\end{array}$ \\
\hline
\end{tabular}


Table 4 Characteristics of included studies (local/regional intervention): Access dimension and outcome (Continued)

$\begin{array}{ll}\text { Tourigny, 2004; } & 24 / 7 \text { access to } \\ \text { Hebert, 2010 } & \text { the Health Info } \\ {[53,64]} & \begin{array}{l}\text { Line for the } \\ \text { assessment of } \\ \text { needs. }\end{array}\end{array}$

Levkoff, 2004;

42

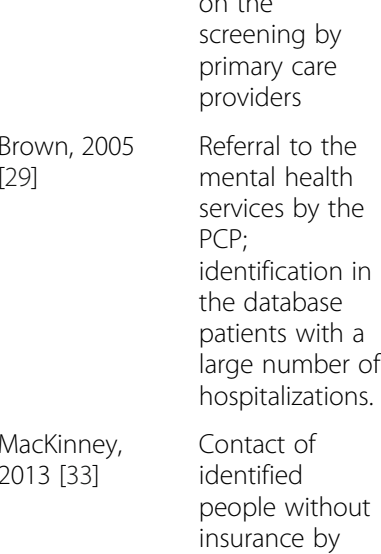

The monitoring

of health

condition was

from home of

participants.

$\begin{array}{lll}\text { "The single } & \text { Intervention in } & \text { The continuous } \\ \text { entry point" } & \text { public health care } & \text { nature of the } \\ \text { mechanism for } & \text { system } & \text { intervention (close } \\ \text { accessing the } & & \text { collaborative work } \\ \text { services in the } & \text { of PCP, case } \\ \text { area for frail } & \text { manager, and } \\ \text { seniors with } & \text { multidisciplinary } \\ \text { complex needs. } & \text { team). }\end{array}$

Co-location of primary care services with mental health services

\section{Co-location of} primary care services with mental health services

from patients.

eam). unemployed

participants)

Timely delivery of Ability to engage:
services based on participation of patients

and healthcare

decision-making regard-

ing of the treatment op-

tions based on the

measurements of vital

signs.

$(p=0.043) ; \quad 10$ days;

$\begin{array}{ll}\text { Decrease } & \text { Decrease } \\ (13 \% \text { vs 6\%; } & (32 \% \text { vs } \\ p<0.03) & 19 \% ; p< \\ & 0.0001)\end{array}$

Decrease in - no need to travel

the number to physician's office

for blood pressure

emergency reading:

- absence of waiting time to have blood pressure read by a

- better access to

access to nursing

and medical

expertise.

- increase of - no

hospitalization difference

within 10 days within

- no difference - higher in

90 days; $\quad(p<0.001)$;

- higher in - no

year $1(31 \%$ difference in

vs $28 \%, p=$

year 3 and 4 .

0.281 )

- no difference

over 4 yea

$(p=0.113)$

got the service patients wanted

$(p=0.01)$;

- service received

met patients needs

$(p=0.0001)$.

Decrease $(p=$ Decrease $(p$

0.02)

$=0.05$ ) 
Table 4 Characteristics of included studies (local/regional intervention): Access dimension and outcome (Continued)

social worker to

offer an access

to primary

health services

$\begin{array}{ll}\text { Bradley, } 2012 & \begin{array}{l}\text { Contact of } \\ \text { [34] }\end{array} \\ & \text { identified } \\ & \text { insurance without } \\ & \text { offer an access } \\ & \text { to primary } \\ & \text { health services }\end{array}$

Kaufman, 2000 Uninsured

[31] patients

according the

eligibility criteria

were enrolled.

\begin{tabular}{|c|c|}
\hline $\begin{array}{l}\text { Primary care } \\
\text { providers } \\
\text { located near the } \\
\text { residence of }\end{array}$ & $\begin{array}{l}\text { Absence of } \\
\text { payment for } \\
\text { primary care } \\
\text { services }\end{array}$ \\
\hline $\begin{array}{l}\text { The program } \\
\text { was eligible for } \\
\text { the residents of } \\
\text { New Mexico } \\
\text { county only. }\end{array}$ & $\begin{array}{l}\text { Small copayment } \\
\text { depending on the } \\
\text { poverty level } \\
\text { (ranged from no } \\
\text { premium to } \$ 10 \\
\text { per patient per } \\
\text { month) }\end{array}$ \\
\hline
\end{tabular}

$$
\begin{array}{ll}
\text { Decrease }(p< & \begin{array}{l}
\text { Decrease }(p \\
0.01)
\end{array} \\
<0.01)
\end{array}
$$

$\begin{array}{llll}\text { Ability to pay: ranged } & \text { Decrease }(p< & \text { Decrease }(p & \begin{array}{l}\text { Decrease of time } \\ \text { for the first } \\ \text { from no payment to a }\end{array} \\ \text { small monthly premium. } & 0.0001) & <0.0001) & \begin{array}{l}\text { appointment with } \\ \text { PCP (from 45 to }\end{array}\end{array}$

28 days).

Roby, 2010 [46] Uninsured

patients were

enrolled at the

sought for

\begin{tabular}{|c|c|c|c|}
\hline $\begin{array}{l}\text { Beland, } 2006 \\
\text { [55] }\end{array}$ & $\begin{array}{l}\text { Intervention } \\
\text { delivered } \\
\text { through the } \\
\text { public } \\
\text { community } \\
\text { organizations } \\
\text { responsible for } \\
\text { home care }\end{array}$ & $\begin{array}{l}\text { The intervention } \\
\text { team physically } \\
\text { was located in } \\
\text { the public } \\
\text { community } \\
\text { organizations }\end{array}$ & $\begin{array}{l}\text { Intervention in } \\
\text { public health care } \\
\text { system }\end{array}$ \\
\hline $\begin{array}{l}\text { Glendenning- } \\
\text { Napoli, } 2012 \\
\text { [30] }\end{array}$ & $\begin{array}{l}\text { Uninsured } \\
\text { patients with } \\
\text { frequent } \\
\text { hospital and } \\
\text { emergency use } \\
\text { were contacted } \\
\text { by the phone } \\
\text { to enroll in the } \\
\text { program. }\end{array}$ & & \\
\hline
\end{tabular}

health services.

Continuity of care via case management

patients at high

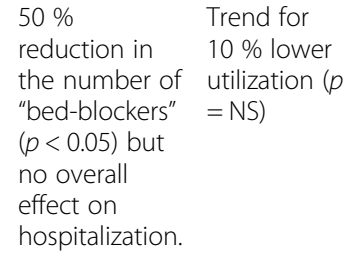


Table 4 Characteristics of included studies (local/regional intervention): Access dimension and outcome (Continued)

$\begin{array}{ll}\text { Services were } & \text { Services were } \\ \text { offered to HIV } & \text { identified in the } \\ \text { patients prior } & \text { neighborhood } \\ \text { their release } & \end{array}$

Patients referred

by PCPS

$\begin{array}{ll}\text { Horwitz, 2005 } & \begin{array}{l}\text { Patients } \\ \text { identified at } \\ \text { [40] }\end{array} \\ & \text { discharge }\end{array}$

Palfrey, 2002; Children already

2004 [32] receiving care

in pediatric

primary care

practices were

approached

professiona

Eligible patients

were those with

existing insurance.

needs

existing insurance.

\begin{tabular}{|c|c|c|}
\hline $\begin{array}{l}\text { B9] } \\
\text { Boult, } 2011 \text { [35, }\end{array}$ & $\begin{array}{l}\text { service use } \\
\text { were contacted } \\
\text { (screening } \\
\text { based on the } \\
\text { insurance } \\
\text { claims) }\end{array}$ & \\
\hline Shah, 2011 [47] & $\begin{array}{l}\text { Uninsured } \\
\text { frequent ED } \\
\text { users were } \\
\text { identified and } \\
\text { enrolled }\end{array}$ & \\
\hline Wang, 2012 [43] & $\begin{array}{l}\text { Mandatory } \\
\text { attendance of } \\
\text { an appointment } \\
\text { with a } \\
\text { community } \\
\text { health worker } \\
\text { within } 2 \text { weeks } \\
\text { of the release } \\
\text { date from the } \\
\text { prison }\end{array}$ & $\begin{array}{l}\text { Health care } \\
\text { services were } \\
\text { provided and } \\
\text { coordinated } \\
\text { by a } \\
\text { healthcare } \\
\text { professional } \\
\text { with a } \\
\text { history of } \\
\text { incarceration. }\end{array}$ \\
\hline ohl, 2011 [37] & Services were & \\
\hline
\end{tabular}

neighborhood

ntervention was

offered to

patients living in

the proximity of

primary care

facilitates

- In-home as-

sessment of

needs and regu-

lar home follow-

up;

- Intervention

was designed

for the residents ath

intervention were

delivered at home (e.g.

assessment of needs)

Ability to engage:

development

individual care plan.

Ability to reach: follow-

up at home and during

Decrease $(p<$ Decrease $(p$

hospitalization;

$<0.0001)$

Ability to engage:

involvement in the

development of the

individual care plan.

No difference Decrease ( $p$

$$
(p=0.34) \quad<0.04)
$$

Individualized care Ability to engage: clients No difference No

plans were were actively involved in difference

developed the development of

according to the care plan for short and

$$
\text { needs }
$$

long-term objectives.

\section{Individualized care Ability to engage:}
plans were
patients were actively

Decrease $(p=$ Decrease $(p$

developed involved in the

according to the development of care

needs

plan.

No difference No

difference

Ability to reach: some

elements of the

Decrease $(p<$ No

intervention were

assessment of needs):

Ability to engage:

involvement in the

development of the
Decrease of unmet

health care needs: - getting a phone

calls returned

(61\%);

- getting an

(60.9\%); 
Table 4 Characteristics of included studies (local/regional intervention): Access dimension and outcome (Continued)

\begin{tabular}{|c|c|c|c|c|c|c|c|c|}
\hline & & $\begin{array}{l}\text { of the particular } \\
\text { neighborhood. }\end{array}$ & & & $\begin{array}{l}\text { individual care plan; } \\
\text { participation of a local } \\
\text { parent consultant in the } \\
\text { development and } \\
\text { amendment of the } \\
\text { intervention. }\end{array}$ & & & $\begin{array}{l}\text { - getting early } \\
\text { medical care } \\
(61.4 \%) ; \\
\text { - getting resources } \\
\text { for a child ( } 59.7 \%) ; \\
\text { - getting letters of } \\
\text { medical necessity } \\
(66.9 \%) \text {; } \\
\text { - communicating } \\
\text { with a child's doctor } \\
(60.9 \%) ; \\
\text { - getting referral } \\
\text { to doctors (60.5 \%). }\end{array}$ \\
\hline $\begin{array}{l}\text { Farmer, } 2005 \\
\text { [27] }\end{array}$ & $\begin{array}{l}\text { Patients referred } \\
\text { to the program } \\
\text { according to } \\
\text { the eligibility } \\
\text { criteria }\end{array}$ & $\begin{array}{l}\text { Children } \\
\text { residing in the } \\
\text { region primary } \\
\text { care clinics } \\
\text { provide health } \\
\text { services for. }\end{array}$ & $\begin{array}{l}\text { Participants were } \\
\text { enrolled in } \\
\text { Medicaid fee-for- } \\
\text { service, Medicaid } \\
\text { managed care, and } \\
\text { commercial health } \\
\text { insurance }\end{array}$ & & $\begin{array}{l}\text { Ability to perceive: } \\
\text { children were already } \\
\text { involved in the services } \\
\text { provided by multiple } \\
\text { medical specialists due } \\
\text { to severe health } \\
\text { disorder/s interfering } \\
\text { their everyday } \\
\text { functioning; } \\
\text { Ability to reach: } \\
\text { comprehensive } \\
\text { assessment of needs } \\
\text { was provided at home; } \\
\text { a web site to ease } \\
\text { access to additional } \\
\text { support services online. } \\
\text { Ability to engage: } \\
\text { involvement in the } \\
\text { development of } \\
\text { individual short-term } \\
\text { family goals. }\end{array}$ & $\begin{array}{l}\text { Decrease }(p= \\
0.55)\end{array}$ & & $\begin{array}{l}\text { Less need for: } \\
\text { - social support } \\
(p=0.03) \text {; } \\
\text { - help with family } \\
\text { relationship } \\
(p=0.015) \text {. }\end{array}$ \\
\hline Druss, 2001 [36] & $\begin{array}{l}\text { Referral of } \\
\text { patients to } \\
\text { primary care by } \\
\text { mental health } \\
\text { providers }\end{array}$ & $\begin{array}{l}\text { Primary care } \\
\text { clinic located } \\
\text { contiguous to } \\
\text { the mental } \\
\text { health clinics }\end{array}$ & & $\begin{array}{l}\text { Development of } \\
\text { the individualized } \\
\text { care plan } \\
\text { according to the } \\
\text { needs of patients. }\end{array}$ & & $\begin{array}{l}\text { Decrease } \\
(8.5 \% \text { vs } 18 \% ; \\
p=0.12)\end{array}$ & $\begin{array}{l}\text { Decrease } \\
(11.9 \% \text { vs } \\
26.2 \% ; p= \\
0.04)\end{array}$ & $\begin{array}{l}\text { Fewer problems } \\
\text { with: } \\
\text { - access to care } \\
(p<0.01) ; \\
\text { - attention to patient } \\
\text { preferences }(p=0.03) ; \\
\text { - courtesy }(p=0.046) ; \\
\text { - coordination of } \\
\text { services }(p=0.01) ; \\
\text { - continuity of } \\
\text { care }(p<0.001) \text {. }\end{array}$ \\
\hline $\begin{array}{l}\text { Counsell, } 2007 \\
\text { [38] }\end{array}$ & $\begin{array}{l}\text { Patients referred } \\
\text { by PCPs }\end{array}$ & & & $\begin{array}{l}\text { Individualized care } \\
\text { plans were } \\
\text { developed }\end{array}$ & $\begin{array}{l}\text { Ability to engage: } \\
\text { patients were actively } \\
\text { involved in the }\end{array}$ & $\begin{array}{l}\text { No difference } \\
\text { except for } \\
\text { high risk } \\
\text { patients }\end{array}$ & $\begin{array}{l}\text { Decrease }(p \\
=0.03)\end{array}$ & \\
\hline
\end{tabular}


Table 4 Characteristics of included studies (local/regional intervention): Access dimension and outcome (Continued)

Institution incentives

\begin{tabular}{|c|c|c|c|}
\hline $\begin{array}{l}\text { Feinglass, } 2014 \\
\text { [28] }\end{array}$ & $\begin{array}{l}\text { Uninsured } \\
\text { residents of } \\
\text { suburban } \\
\text { DuPage County } \\
\text { with a } \\
\text { household } \\
\text { income below } \\
200 \% \text { of } \\
\text { Federal Poverty } \\
\text { Level were } \\
\text { assigned. }\end{array}$ & $\begin{array}{l}\text { Program was } \\
\text { implemented in } \\
45 \text { sites across } \\
\text { the county. }\end{array}$ & $\begin{array}{l}\text { County hospitals, } \\
\text { county } \\
\text { government, and } \\
\text { other foundations } \\
\text { financially } \\
\text { supported the } \\
\text { program. } \\
\text { Moreover, the } \\
\text { Access DuPage } \\
\text { program pays a } \\
\text { small capitated fee } \\
\text { to clinics and PCPs. }\end{array}$ \\
\hline
\end{tabular}

ccording to the

needs

Individualized care

plans were

developed

according to the

needs

plan

Intervention in

public health care

system

\section{Continuous nature}

of care: from

discharge to

asthma control by

PCP

$\begin{array}{ll}\text { To have an } & \text { Free access to } \\ \text { access to the } & \text { health care services }\end{array}$

access to the

patients have to

reside in the

target area zip

intervention

ED admission

code.

Ability to pay: only a

small copayment was

$14 \%$

required for the

prescribed medications. (decrease, $p=$

0.03).

No difference

(29.8\% vs

$24.6 \%, p=$

$0.59)$

Decrease at $3(p=0.53)$ and 6 months $(p=0.27)$ but no difference at 12 months ( $p=$ 0.63).

Decrease ( $p$

$<0.01)$
- decrease of waiting time to see a doctor/ nurse $(p=N S)$; - increase of clinic working hours $(p<0.0001)$;

- increase access trough the phone $(p<0.05)$; - increase of ease to get an appointment $(p<0.05)$;

- increase of ease to get transportation $(p<0.05)$ - increase of receiving care participants thought they needed (e.g., blood tests, appointment with a doctor) $(p<0.0001)$;

- increase of satisfaction to communicate with

a doctor/nurse

(due to language barrier) $(p<0.0001)$ 
nurses give $(p<0.05)$

- increase of time

healthcare professionals

spend with patients

$(p<0.05)$

- satisfaction with respect

healthcare professionals

show $(p<0.05)$ 


\section{Appendix 3}

Table 5 Characteristics of included studies (state/national intervention): Access dimension and outcome

\begin{tabular}{|c|c|c|c|c|c|c|c|c|c|}
\hline \multirow[t]{2}{*}{ Study ID } & \multicolumn{5}{|c|}{ Dimensions of access of primary care services } & \multirow{2}{*}{$\begin{array}{l}\text { Dimensions of ability } \\
\text { of consumers } \\
\text { Ability to (1) Perceive; } \\
\text { (2) Seek; (3) Reach; (4) } \\
\text { Pay; (5) Engage }\end{array}$} & \multicolumn{3}{|l|}{ Outcomes } \\
\hline & Approachability & Acceptability & $\begin{array}{l}\text { Availability and } \\
\text { Accommodation }\end{array}$ & Affordability & Appropriateness & & $\begin{array}{l}\text { Avoidable } \\
\text { hospitalization }\end{array}$ & $\begin{array}{l}\text { Avoidable ED } \\
\text { admission }\end{array}$ & $\begin{array}{l}\text { Unmet health } \\
\text { care needs }\end{array}$ \\
\hline \multicolumn{10}{|c|}{ Clinical multidisciplinary teams } \\
\hline $\begin{array}{l}\text { McDermott, } \\
2004 \text { [62] }\end{array}$ & $\begin{array}{l}\text { Implementation } \\
\text { of diabetes } \\
\text { registers, recall } \\
\text { and reminder } \\
\text { systems }\end{array}$ & $\begin{array}{l}\text { Delivery of } \\
\text { services by } \\
\text { the local } \\
\text { indigenous } \\
\text { health } \\
\text { workers }\end{array}$ & $\begin{array}{l}\text { Delivery of the } \\
\text { diabetes health } \\
\text { services in the } \\
\text { remote } \\
\text { indigenous } \\
\text { communities. }\end{array}$ & & & & $\begin{array}{l}\text { - } 32 \% \text { reduction } \\
\text { of hospitalization } \\
\text { for diabetes-related } \\
\text { conditions }(p=0.012) \text {; } \\
\text { - Decline of } \\
\text { hospitalization from } \\
25 \% \text { to } 20 \% \text { over } \\
3 \text { years (2004). }\end{array}$ & & \\
\hline \multicolumn{10}{|c|}{ Continuity of care via case management } \\
\hline $\begin{array}{l}\text { Dorr, } 2008 \\
\text { [49] }\end{array}$ & $\begin{array}{l}\text { Patients referred } \\
\text { by PCPs }\end{array}$ & & & & $\begin{array}{l}\text { Individualized } \\
\text { care plans were } \\
\text { developed } \\
\text { according to } \\
\text { the needs }\end{array}$ & $\begin{array}{l}\text { Ability to engage: } \\
\text { patients were actively } \\
\text { involved in the } \\
\text { development of care } \\
\text { plan }\end{array}$ & $\begin{array}{l}\text { Decrease } \\
(p=0.55)\end{array}$ & $\begin{array}{l}\text { By } 2 \text { years of follow-up: } \\
\text { increase ( } p=0.02 \text { for all } \\
\text { patients, } p=0.37 \text { for } \\
\text { patients with diabetes) }\end{array}$ & \\
\hline $\begin{array}{l}\text { Gravelle, } \\
2007 \text { [60] }\end{array}$ & $\begin{array}{l}\text { Patients } \\
\text { identified based } \\
\text { on the age and } \\
\text { frequency of } \\
\text { emergency use }\end{array}$ & & & $\begin{array}{l}\text { No additional } \\
\text { payment }\end{array}$ & $\begin{array}{l}\text { Individualized } \\
\text { care plans were } \\
\text { developed } \\
\text { according to } \\
\text { the needs }\end{array}$ & $\begin{array}{l}\text { Ability to engage: } \\
\text { patients were actively } \\
\text { involved in the } \\
\text { development of care } \\
\text { plan }\end{array}$ & & No effect $(p=0.14)$ & \\
\hline $\begin{array}{l}\text { Landi, } 2001 \\
\text { [63] }\end{array}$ & $\begin{array}{l}\text { Patients referred } \\
\text { by PCPs }\end{array}$ & & $\begin{array}{l}\text { Integration of all } \\
\text { the community- } \\
\text { based services } \\
\text { and services } \\
\text { provided by the } \\
\text { health agency/ } \\
\text { municipality into } \\
\text { one "single } \\
\text { enter" center }\end{array}$ & & $\begin{array}{l}\text { Individualized } \\
\text { care plans were } \\
\text { developed } \\
\text { according to } \\
\text { the needs }\end{array}$ & $\begin{array}{l}\text { Ability to engage: } \\
\text { patients were actively } \\
\text { involved in the } \\
\text { development of care } \\
\text { plan }\end{array}$ & $\begin{array}{l}\text { Decrease by } \\
18 \% \\
(p<0.001)\end{array}$ & & \\
\hline
\end{tabular}

Institution incentives

Addink, 2011 
Table 5 Characteristics of included studies (state/national intervention): Access dimension and outcome (Continued)

$\begin{array}{lll}\begin{array}{ll}\text { The whole } \\ \text { population is }\end{array} & \text { Services were } & \text { developed } \\ \text { eligible } & \text { with active } & \text { Depending on } \\ \text { partnership } & \text { the income } \\ \text { of ethnic } & \text { level: very low } \\ \text { communities } & \text { fees (free to } \\ \text { (iwi) } & \$ 15 \text { for all } \\ & \text { ages), low } \\ & \text { fees } \\ & (\$ 16-\$ 30), \\ & \text { medium } \\ & (\$ 31-\$ 39), \\ & \text { high }(\$ 40 \text { or } \\ & \text { above). }\end{array}$
Ability to engage: representatives of local ethnic
communities were
the devely inved in
the development
care programs

\section{Ability to pay: no}

charge as these

managed care

programs are funded

by the State.
- ability to book an

appointment in

advance $(4.42 \%$ of

increase);

- ability to see a

particular PCP

(1.21\% of increase):

- satisfaction with

opening hours (1.25\%

of decrease).

$4 \%$ decrease over Enrolled patients

five years

contributed to

$0.2 \%$ increase in

comparison to $1.7 \%$

increase of not enrolled

(overall steady increase

of $2 \%$ per year).

Slight reduction

(3.8\% points)

No effect on unmet

State
Children's

$(p=N S)$ medical care needs

insurance 


\section{Abbreviations}

EPOC: Cochrane Effective Practice and Organization of Care Review Group: IMPACT: Improving Models Promoting Access-to-Care Transformation; OECD: Organization for Economic Cooperation and Development

\section{Acknowledgements}

Pierre Pluye holds a Senior Investigator salary award from the 'Fonds de recherche en santé du Québec' (FRQS). This review was supported by IMPACT, the 'Improving Models Promoting Access-to-Care Transformation' program. This program is funded by the Canadian Institutes of Health Research (TTF-130729) Signature Initiative in Community-Based Primary Health Care, the FRQS, and the Australian Primary Health Care Research Institute, which is supported by a grant from the Australian Government Department of Health, under the Primary Health Care Research, Evaluation and Development Strategy. The information and opinions contained in this article do not necessarily reflect the views or policy of these funding agencies.

\section{Funding}

This project was funded by IMPACT, the 'Improving Models Promoting Access-to-Care Transformation' program, Canadian Institutes of Health Research (TTF-130729) Signature Initiative in Community-Based Primary Health Care, the FRQS, and the Australian Primary Health Care Research Institute.

\section{Availability of data and material}

Please contact authors for data request.

\section{Competing interests}

All co-authors declare that they have no competing interests.

\section{Authors' contributions}

All co-authors contributed to this review (conception and design, data extraction and synthesis, and interpretation of results). They were involved in presenting a work-in-progress poster at the 2014 conference of the North American Primary Care Research Group (NAPCRG). They revised the manuscript and approved the final version.

\section{Consent for publication}

Not applicable.

\section{Ethics approval and consent to participate}

Not applicable.

\section{Author details}

'Department of Family Medicine, McGill University, 5858 Côte-des-neiges, 3rd Floor, Suite 300, Montreal, QC H3S 1Z1, Canada. ${ }^{2}$ St. Mary's Hospital Research Centre, 3830 Lacombe Ave, Montréal, QC H3T1M5, Canada. ${ }^{3}$ Department of Family Medicine, McGill University, St. Mary's Hospital Research Centre, 3830 Lacombe Ave, Montréal, QC H3T1M5, Canada. ${ }^{4}$ Southern Academic Primary Care Research Unit, Department of General Practice, School of Primary Health Care, Monash University, Building 1, 270 Ferntree Gully Rd, Notting Hill, VIC 3168, Australia. ${ }^{5}$ University of Melbourne, 200 Berkeley Street, Melbourne, VIC 3053, Australia. ${ }^{6}$ Centre for Primary Health Care and Equity, University of New South Wales, Bureau of Health Information, 67 Albert Avenue, Chatswood, Sydney, NSW 2067, Australia.

Received: 5 April 2016 Accepted: 3 October 2016 Published online: 10 October 2016

\section{References}

1. Levesque JF, Pineault R, Hamel M, Roberge D, Kapetanakis C, Simard B, et al. Emerging organisational models of primary healthcare and unmet needs for care: insights from a population-based survey in Quebec province. BMC Fam Pract. 2012;13:66. doi:10.1186/1471-2296-13-66.

2. Asada Y, Kephart G. Equity in health services use and intensity of use in Canada. BMC Health Serv Res. 2007;7:41. doi:10.1186/1472-6963-7-41.

3. Bowen S. Access to health services for underserved populations in Canada. Ottawa: Health Canada; 2012.

4. Harris M, Furler J, Valenti L. Matching care to need in general practice: a secondary analysis of BEACH data. Aust J Prim Health. 2004;10:151-5.
5. Spike EA, Smith MM, Harris MF. Access to primary health care services by community-based asylum seekers. Med J Aust. 2011;195(4):188-91.

6. Khandor E, Mason K, Chambers C, Rossiter K, Cowan L, Hwang SW. Access to primary health care among homeless adults in Toronto, Canada: results from the Street Health survey. Open Med. 2011;5(2):e94-103.

7. Healthier Future for All Australians. Final Report of the National Health and Hospitals Reform Commission. Canberra: Healthier Future for All Australians; 2009

8. Hutchison B, Levesque JF, Strumpf E, Coyle N. Primary health care in Canada: systems in motion. Milbank Q. 2011;89(2):256-88. doi:10.1111/j. 1468-0009.2011.00628.x.

9. Levesque JF, Harris MF, Russell G. Patient-centred access to health care: conceptualising access at the interface of health systems and populations. International Journal for Equity in Health. 2013;12:18. doi:10.1186/1475-9276-12-18.

10. Coulter A, Ellins J. Patient-focused interventions: A review of the evidence. Oxford: The Health Foundation, Picker Institute Europe; 2006.

11. Arskey H, O'Malley L. Scoping studies: towards a methodological framework. International Journal of Social Research Methodology. 2005;8(1):19-32.

12. Levac D, Colquhoun H, O'Brien KK. Scoping studies: advancing the methodology. Implementation Science. 2010;5:69. doi:10.1186/17485908-5-69.

13. Colquhoun HL, Levac D, O'Brien KK, Straus S, Tricco AC, Perrier L, et al. Scoping reviews: time for clarity in definition, methods, and reporting. J Clin Epidemiol. 2014;67(12):1291-4. doi:10.1016/j.jclinepi.2014.03.013.

14. Tricco AC, Lillie E, Zarin W, O'Brien K, Colquhoun H, Kastner M, et al. A scoping review on the conduct and reporting of scoping reviews. BMC Med Res Methodol. 2016;16:15. doi:10.1186/s12874-016-0116-4.

15. Khanassov V, Vedel I. Family physician-case manager collaboration and needs of patients with dementia and their caregivers: a systematic mixed studies review. Ann Fam Med. 2016;14(2):166-77. doi:10.1370/afm.1898.

16. Khanassov V, Vedel I, Pluye P. Barriers to implementation of case management for patients with dementia: a systematic mixed studies review. Ann Fam Med. 2014;12(5):456-65. doi:10.1370/afm.1677.

17. Khanassov V, Vedel I, Pluye P. Case management for dementia in primary health care: a systematic mixed studies review based on the diffusion of innovation model. Clin Interv Aging. 2014;9:915-28. doi:10.2147/cia.564723.

18. Hsieh H-F, Shannon SE. Three Approaches to Qualitative Content Analysis. Qual Health Res. 2005;15(9):1277-88. doi:10.1177/1049732305276687.

19. Cochrane Effective Practice and Organisation of Care Group (EPOC). http://epoc.cochrane.org/. Accessed 22 Sept 2016.

20. Billings J, Anderson GM, Newman LS. Recent findings on preventable hospitalizations. Health Aff (Millwood). 1996;15(3):239-49.

21. Huntley A, Lasserson D, Wye L, Morris R, Checkland K, England H, et al. Which features of primary care affect unscheduled secondary care use? A systematic review. BMJ Open. 2014;4(5):e004746. doi:10.1136/bmjopen-2013-004746.

22. McCusker J, Roberge D, Levesque JF, Ciampi A, Vadeboncoeur A, Larouche $D$, et al. Emergency department visits and primary care among adults with chronic conditions. Med Care. 2010;48(11):972-80. doi:10.1097/MLR. ob013e3181eaf86d.

23. Ronksley PE, Sanmartin C, Campbell DJ, Weaver RG, Allan GM, McBrien KA et al. Perceived barriers to primary care among western Canadians with chronic conditions. Health Rep. 2014:25(4):3-10.

24. Canadian Institutes of Health Research. http://www.cihr-irsc.gc.ca/e/44000.html.

25. Davidoff A, Hill I, Courtot B, Adams E. Are there differential effects of managed care on publicly insured children with chronic health conditions? Med Care Res Rev. 2008;65(3):356-72. doi:10.1177/1077558707312492.

26. Garg A, Marino M, Vikani AR, Solomon BS. Addressing families' unmet social needs within pediatric primary care: the health leads model. Clin Pediatr (Phila). 2012;51(12):1191-3. doi:10.1177/0009922812437930.

27. Farmer JE, Clark MJ, Sherman A, Marien WE, Selva TJ. Comprehensive primary care for children with special health care needs in rural areas. Pediatrics. 2005;116(3):649-56. doi:10.1542/peds.2004-0647.

28. Feinglass J, Nonzee NJ, Murphy KR, Endress R, Simon MA. Access to care outcomes: a telephone interview study of a suburban safety net program for the uninsured. J Community Health. 2014;39(1):108-17. doi:10.1007/ s10900-013-9746-1.

29. Brown KE, Levine JM, Fiellin DA, O'Connor P, Sledge WH. Primary intensive care: pilot study of a primary care-based intervention for high-utilizing patients. Dis Manag. 2005;8(3):169-77. doi:10.1089/dis.2005.8.169. 
30. Glendenning-Napoli A, Dowling B, Pulvino J, Baillargeon G, Raimer BG. Community-based case management for uninsured patients with chronic diseases: effects on acute care utilization and costs. Prof Case Manag. 2012; 17(6):267-75. doi:10.1097/NCM.0b013e3182687f2b.

31. Kaufman A, Derksen D, McKernan S, Galbraith P, Sava S, Wills J, et al. Managed care for uninsured patients at an academic health center: a case study. Acad Med. 2000;75(4):323-30

32. Palfrey JS, Sofis LA, Davidson EJ, Liu J, Freeman L, Ganz ML. The Pediatric Alliance for Coordinated Care: evaluation of a medical home model. Pediatrics. 2004;113(5 Suppl):1507-16.

33. Mackinney T, Visotcky AM, Tarima S, Whittle J. Does providing care for uninsured patients decrease emergency room visits and hospitalizations? J Prim Care Community Health. 2013;4(2):135-42. doi:10.1177/ 2150131913478981.

34. Bradley CJ, Gandhi SO, Neumark D, Garland S, Retchin SM. Lessons for coverage expansion: a Virginia primary care program for the uninsured reduced utilization and cut costs. Health Aff (Millwood). 2012;31(2):350-9. doi:10.1377/hlthaff.2011.0857.

35. Leff B, Reider L, Frick KD, Scharfstein DO, Boyd CM, Frey K, et al. Guided care and the cost of complex healthcare: a preliminary report. Am J Manag Care. 2009; 15(8):555-9.

36. Druss BG, Rohrbaugh RM, Levinson CM, Rosenheck RA. Integrated medical care for patients with serious psychiatric illness: a randomized trial. Arch Gen Psychiatry. 2001;58(9):861-8.

37. Wohl DA, Scheyett A, Golin CE, White B, Matuszewski J, Bowling M, et al. Intensive case management before and after prison release is no more effective than comprehensive pre-release discharge planning in linking HIV-infected prisoners to care: a randomized trial. AIDS Behav. 2011;15(2):356-64. doi:10.1007/s10461-010-9843-4.

38. Counsell SR, Callahan CM, Clark DO, Tu W, Buttar AB, Stump TE, et al. Geriatric care management for low-income seniors: a randomized controlled trial. JAMA. 2007;298(22):2623-33. doi:10.1001/jama.298.22.2623.

39. Sylvia ML, Griswold M, Dunbar L, Boyd CM, Park M, Boult C. Guided care: cost and utilization outcomes in a pilot study. Dis Manag. 2008;11(1):29-36. doi:10.1089/dis.2008.111723.

40. Horwitz SM, Busch SH, Balestracci KM, Ellingson KD, Rawlings J. Intensive intervention improves primary care follow-up for uninsured emergency department patients. Acad Emerg Med. 2005;12(7):647-52. doi:10.1197/j. aem.2005.02.015.

41. Levkoff SE, Chen H, Coakley E, Herr EC, Oslin DW, Katz I, et al. Design and sample characteristics of the PRISM-E multisite randomized trial to improve behavioral health care for the elderly. J Aging Health. 2004;16(1):3-27.

42. Chen H, Coakley EH, Cheal K, Maxwell J, Costantino G, Krahn DD, et al. Satisfaction with mental health services in older primary care patients. Am J Geriatr Psychiatry. 2006;14(4):371-9. doi:10.1097/01.JGP.0000196632.65375.b9.

43. Wang EA, Hong CS, Shavit S, Sanders R, Kessell E, Kushel MB. Engaging individuals recently released from prison into primary care: a randomized trial. Am J Public Health. 2012;102(9):e22-9. doi:10.2105/ajph.2012.300894.

44. Michelen W, Martinez J, Lee A, Wheeler DP. Reducing frequent flyer emergency department visits. J Health Care Poor Underserved. 2006;17(1 Suppl):59-69. doi:10.1353/hpu.2006.0010.

45. McCulloch D, Price M, Hindmarsh M, Wagner EH. Improvement in diabetes care using an integrated population-based approach in a primary care setting. DM. 2000;3(2):75-82.

46. Roby DH, Pourat N, Pirritano MJ, Vrungos SM, Dajee H, Castillo D, et al Impact of patient-centered medical home assignment on emergency room visits among uninsured patients in a county health system. Med Care Res Rev. 2010;67(4):412-30. doi:10.1177/1077558710368682

47. Shah R, Chen C, O'Rourke S, Lee M, Mohanty SA, Abraham J. Evaluation of care management for the uninsured. Med Care. 2011;49(2):166-71. doi:10. 1097/MLR.0b013e3182028e81.

48. DeHaven M, Kitzman-Ulrich H, Gimpel N, Culica D, O'Neil L, Marcee A, et al. The effects of a community-based partnership, Project Access Dallas (PAD), on emergency department utilization and costs among the uninsured. J Public Health (Oxf). 2012;34(4):577-83. doi:10.1093/pubmed/fds027.

49. Dorr DA, Wilcox AB, Brunker CP, Burdon RE, Donnelly SM. The effect of technology-supported, multidisease care management on the mortality and hospitalization of seniors. J Am Geriatr Soc. 2008:56(12):2195-202. doi:10.1111/j.1532-5415.2008.02005.x.

50. Driscoll DL, Hiratsuka V, Johnston JM, Norman S, Reilly KM, Shaw J, et al. Process and outcomes of patient-centered medical care with Alaska Native people at Southcentral Foundation. Ann Fam Med. 2013;11 Suppl 1:S41-9. doi:10.1370/afm.1474.

51. Callahan C, Boustani M, Unverzagt F, Austrom M, Damush T, Perkins A, et al. Effectiveness of collaborative care for older adults with Alzheimer disease in primary care: a randomized controlled trial. JAMA. 2006;295(18):2148-57. doi:10.1001/jama.295.18.2148.

52. Crustolo AM, Ackerman S, Kates N, Schamehorn S. Integrating nutrition services into primary care: experience in Hamilton, Ont. Can Fam Physician. 2005:51:1647-53.

53. Hebert R, Raiche M, Dubois MF, Gueye NR, Dubuc N, Tousignant M. Impact of PRISMA, a coordination-type integrated service delivery system for frail older people in Quebec (Canada): A quasi-experimental study. J Gerontol B Psychol Sci Soc Sci. 2010;65b(1):107-18. doi:10.1093/geronb/gbp027.

54. Doye T, Hines P, Myslik B, Leavey J. Creating primary care access for mental health care clients in a community mental health setting. Can J Commun Ment Health. 2008;27(2):129-38.

55. Beland F, Bergman H, Lebel P, Clarfield AM, Tousignant P, Contandriopoulos $A P$, et al. A system of integrated care for older persons with disabilities in Canada: results from a randomized controlled trial. J Gerontol A Biol Sci Med Sci. 2006;61(4):367-73.

56. Lamothe L, Fortin JP, Labbe F, Gagnon MP, Messikh D. Impacts of telehomecare on patients, providers, and organizations. Telemed J E Health 2006:12(3):363-9. doi:10.1089/tmj.2006.12.363.

57. Sin DD, Bell NR, Man SF. Effects of increased primary care access on process of care and health outcomes among patients with asthma who frequent emergency departments. Am J Med. 2004;117(7):479-83. doi:10.1016/j. amjmed.2004.04.011.

58. Addink RW, Bankart MJ, Murtagh GM, Baker R. Limited impact on patient experience of access of a pay for performance scheme in England in the first year. Eur J Gen Pract. 2011;17(2):81-6. doi:10.3109/13814788.2011.556720

59. Boult $C$, Reider $L$, Leff $B$, Frick KD, Boyd CM, Wolff JL, et al. The effect of guided care teams on the use of health services: results from a clusterrandomized controlled trial. Arch Intern Med. 2011;171(5):460-6. doi:10. 1001/archinternmed.2010.540.

60. Gravelle H, Dusheiko M, Sheaff R, Sargent P, Boaden R, Pickard S, et al. Impact of case management (Evercare) on frail elderly patients: controlled before and after analysis of quantitative outcome data. BMJ. 2007;334(7583): 31. doi:10.1136/bmj.39020.413310.55

61. Gray S, Lennon D, Anderson P, Stewart J, Farrell E. Nurse-led school-based clinics for skin infections and rheumatic fever prevention: results from a pilot study in South Auckland. N Z Med J. 2013;126(1373):53-61.

62. McDermott $R$, Tulip F, Sinha A. Sustaining better diabetes care in remote indigenous Australian communities. Qual Saf Health Care. 2004;13(4):295-8. doi:10.1136/qhc.13.4.295.

63. Landi F, Onder G, Russo A, Tabaccanti S, Rollo R, Federici S, et al. A new model of integrated home care for the elderly: impact on hospital use. J Clin Epidemiol. 2001;54(9):968-70.

64. Tourigny A, Durand P, Bonin L, Hebert R, Rochette L. Quasi-experimental study of the effectiveness of an integrated service delivery network for the frail elderly. Can J Aging. 2004;23(3):231-46.

65. Day $\mathrm{C}$, Davis $\mathrm{H}$. The effectiveness and quality of routine child and adolescent mental health care outreach clinics. Br J Clin Psychol. 2006:45(Pt 4):439-52. doi:10.1348/014466505x79986.

66. Tan L, Carr J, Reidy J. New Zealand evidence for the impact of primary healthcare investment in Capital and Coast District Health Board. N Z Med J. 2012;125(1352):7-27.

67. Davidoff A, Hill I, Courtot B, Adams E. Effects of managed care on service use and access for publicly insured children with chronic health conditions. Pediatrics. 2007;119(5):956-64. doi:10.1542/peds.2006-2222.

68. Mann KV, McFetridge-Durdle J, Martin-Misener R, Clovis J, Rowe R, Beanlands $\mathrm{H}$, et al. Interprofessional education for students of the health professions: the "Seamless Care" model. J Interprof Care. 2009;23(3):224-33. doi:10.1080/13561820802697735

69. Jones EJ, Mackinnon NJ, Tsuyuki RT. Pharmaceutical care in community pharmacies: practice and research in Canada. Ann Pharmacother. 2005;39(9): 1527-33. doi:10.1345/aph.1E456.

70. Kelly BJ, Perkins DA, Fuller JD, Parker SM. Shared care in mental illness: A rapid review to inform implementation. Int J Ment Health Syst. 2011:5:31. doi:10.1186/1752-4458-5-31. 
71. Kates N, Mazowita G, Lemire F. The evolution of collaborative mental health care in canada: A shared vision for the future. Can J Psychiatry. 2011;56(5):11.

72. Nadeau L, Rousseau C, Measham T. Addressing cultural diversity through collaborative care. Cultural consultation: Encountering the other in mental health care. 2014.

73. Chapman $\mathrm{J}$, Zechel A, Carter YH, Abbott S. Systematic review of recent innovations in service provision to improve access to primary care. $\mathrm{Br} J \mathrm{Gen}$ Pract. 2004;54(502):374-81

Submit your next manuscript to BioMed Central and we will help you at every step:

- We accept pre-submission inquiries

- Our selector tool helps you to find the most relevant journal

- We provide round the clock customer support

- Convenient online submission

- Thorough peer review

- Inclusion in PubMed and all major indexing services

- Maximum visibility for your research

Submit your manuscript at www.biomedcentral.com/submit 